\title{
Integrated field, satellite and petrological observations of the November 2010 eruption of Erta Ale
}

\author{
Lorraine Field • Talfan Barnie • Jon Blundy • \\ Richard A. Brooker • Derek Keir • Elias Lewi • \\ Kate Saunders
}

Received: 5 January 2012 / Accepted: 10 September 2012 /Published online: 12 October 2012

(C) Springer-Verlag Berlin Heidelberg 2012

\begin{abstract}
Erta Ale volcano, Ethiopia, erupted in November 2010, emplacing new lava flows on the main crater floor, the first such eruption from the southern pit into the main crater since 1973, and the first eruption at this remote volcano in the modern satellite age. For many decades, Erta Ale has contained a persistently active lava lake which is ordinarily confined, several tens of metres below the level of the main crater, within the southern pit. We combine on-the-ground field observations with multispectral imaging from the SEVIRI satellite to reconstruct the entire eruptive episode beginning on 11 November and ending prior to 14 December 2010. A period of quiescence occurred between 14 and 19 November. The main eruptive activity developed between 19 and 22 November, finally subsiding to pre-eruptive levels
\end{abstract}

Editorial responsibility: J.E. Gardner

Electronic supplementary material The online version of this article (doi:10.1007/s00445-012-0660-7) contains supplementary material, which is available to authorized users.

L. Field $(\bowtie) \cdot$ J. Blundy $\cdot$ R. A. Brooker $\cdot$ K. Saunders

School of Earth Sciences, University of Bristol,

Queen's Road,

Bristol BS8 1RJ, UK

e-mail: 1.p.field@gmail.com

T. Barnie

Department of Geography, University of Cambridge,

Downing Place,

Cambridge CB2 3EN, UK

D. Keir

National Oceanography Centre Southampton,

University of Southampton Waterfront Campus,

European Way,

Southampton SO14 3ZH, UK

E. Lewi

Geophysical Observatory, University of Addis Ababa,

Addis Ababa, Ethiopia between 8 and 15 December. The estimated total volume of lava erupted is $\sim 0.006 \mathrm{~km}^{3}$. The mineralogy of the 2010 lava is plagioclase +clinopyroxene+olivine. Geochemically, the lava is slightly more mafic than previously erupted lava lining the caldera floor, but lies within the range of historical lavas from Erta Ale. SIMS analysis of olivine-hosted melt inclusions shows the Erta Ale lavas to be relatively volatile-poor, with $\mathrm{H}_{2} \mathrm{O}$ contents $\leq 1,300 \mathrm{ppm}$ and $\mathrm{CO}_{2}$ contents of $\leq 200 \mathrm{ppm}$. Incompatible trace and volatile element systematics of melt inclusions show, however, that the November 2010 lavas were volatile-saturated, and that degassing and crystallisation occurred concomitantly. Volatile saturation pressures are in the range $7-42 \mathrm{MPa}$, indicating shallow crystallisation. Calculated pre-eruption and melt inclusion entrapment temperatures from mineral/liquid thermometers are $\sim 1,150{ }^{\circ} \mathrm{C}$, consistent with previously published field measurements.

Keywords Afar · Ethiopia - Remote sensing of volcanoes . Lava lake $\cdot$ Melt inclusions $\cdot$ Basalt

\section{Introduction}

The Afar depression lies at the triple junction between the Red Sea, Gulf of Aden and East African rifts, and has been produced by rifting between Africa and Arabia over the past $\sim 30 \mathrm{Myr}$ (Wolfenden et al. 2005). The southern Red Sea rift has become punctuated over the past $\sim 3$ million years with $\sim 60-\mathrm{km}$ long magmatic segments as faulting and volcanic activity have become more focused into localised regions (Barberi and Varet 1977). Erta Ale is a basaltic shield volcano $\left(13^{\circ} 36^{\prime} 11.41^{\prime \prime} \mathrm{N}, 40^{\circ} 39^{\prime} 50.08^{\prime \prime} \mathrm{E}\right)$ situated within the Erta Ale magmatic segment (Fig. 1) which comprises six main volcanic centres (Barberi and Varet 1970). The Erta Ale segment is the northernmost in Afar and forms the sub-aerial southwards 
Fig. 1 Sketch map indicating the location of Erta Ale and satellite image of the Erta Ale crater, with the extent of the November-December 2010 eruption lavas $\left[\sim 0.4 \mathrm{~km}^{2}\right.$ : GPS track courtesy of James Hammond (February 2011)]. Sample locations from 22 November are shown, which were subsequently covered by further overflows. Image taken by the PRISM instrument on ALOS satellite, with an image resolution of $2.5 \mathrm{~m}$. Image acquired on 19 November 2008. Data acquired from ESA

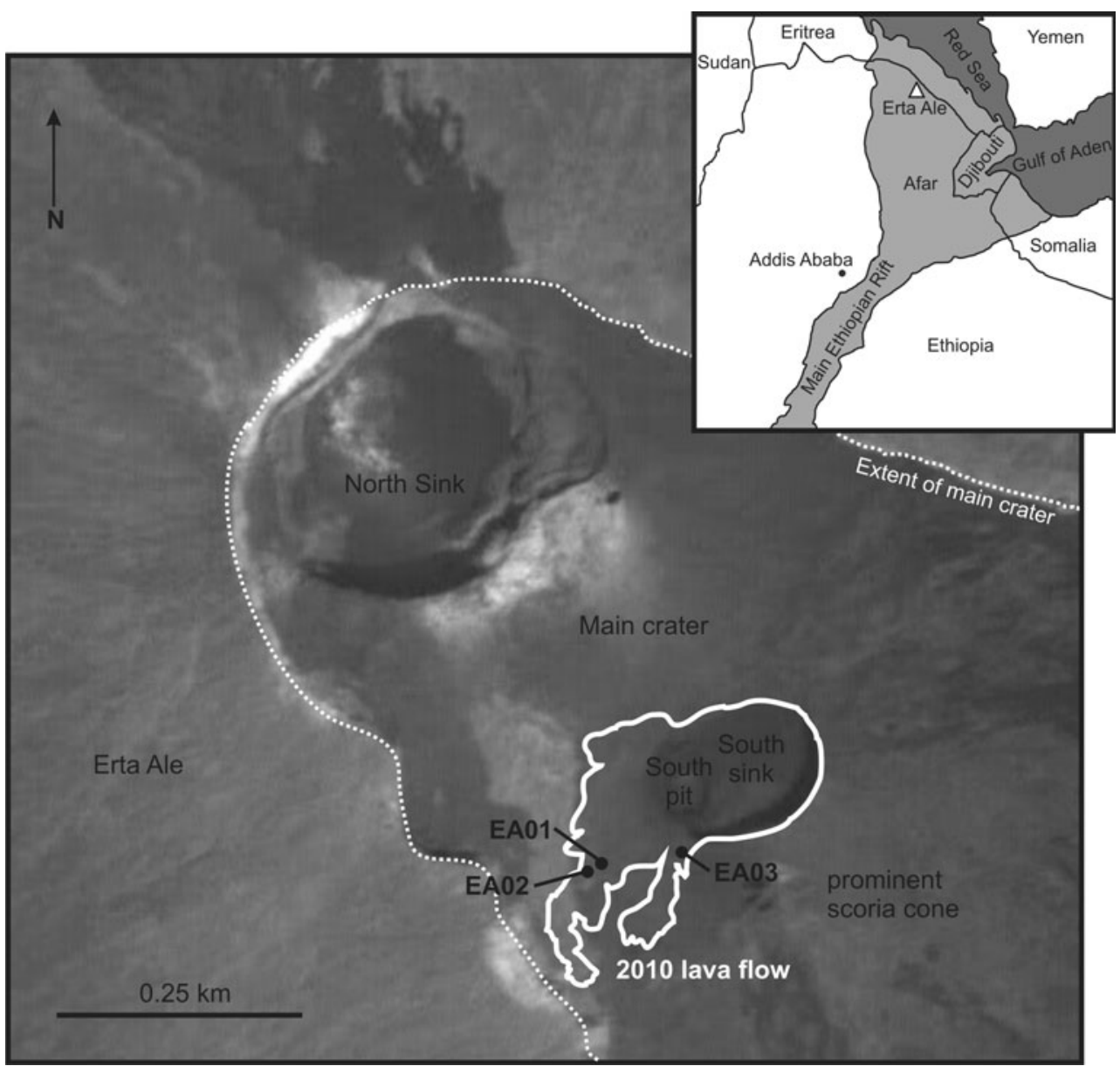

continuation of the Red Sea rift (Prodehl et al. 1997). The last eruption in this segment occurred in November 2008 when basaltic lava covered $15 \mathrm{~km}^{2}$, originating from a fissure between Dalaffilla and Alu volcanoes (Pagli et al. 2012).

Erta Ale is known for its active lava lakes situated in the northern and southern pits within a main $0.7 \times 1.6-\mathrm{km}$ elliptical summit crater (Fig. 1; a summary of recorded activity is provided in Supplementary Table 5). The Erta Ale lava lake is one of just four long-lived lava lakes existing across the world; others are Erebus (Antarctica), Nyiragongo (DR Congo) and Ambrym (Vanuatu). Shorter-lived lava lakes also appear elsewhere periodically, e.g. Kilauea, Hawaii and Villarrica, Chile.

The first systematic study of the Erta Ale lava lake began in 1967 (Barberi and Varet 1970), but the lake is likely to have existed from much earlier than this, as reports of a 'smoking mountain' and characteristic red summit glow were recorded by early visitors to the area (e.g. Nesbitt 1935; Dainelli and Marinelli 1907; Barberi and Varet 1970). Erta Ale volcano is remote and difficult to access, and as a result, observations have been sporadic: it was not until the CNR-CNRS campaigns of the late 1960s that it began to be studied in detail (e.g. Barberi and Varet 1970; Tazieff 1973). At this time, a lava lake existed in both the northern and southern pits, but the northern lake solidified between 1988 and 1992 following emplacement of two lava flows during this period (Vetsch et al. 1992). The southern lake's surface solidified briefly between late 2004 and April 2005 (Bardintzeff and Gaudru 2004; Yirgu and Philpotts 2005). It was reactivated in September 2005, with lava visibly overturning at the edges of the lava lake, within the pit, possibly in response to the volcanoseismic crisis in Afar (Ayele et al. 2007). The level of the southern lake has fluctuated (Le Guern et al. 1979), but the majority of recent observations indicate the lake level was generally tens of metres below the floor of the main crater, nestled at the base of the southern pit (e.g. Oppenheimer and Francis 1997). Eruptions occur from these lakes from time to time, causing lava to overflow from the pits onto the main crater floor, but they are rarely observed. Varet (1972a), reported the first recorded eruptive event from the southern pit in March 1972, following the emplacement of two new lava flows into the main crater which emanated from the southern side of the south pit; one sometime prior to 21 and one on 23 of March. This activity continued with three additional new lava flows, visible when the volcano was visited in May 1972 (Varet 1972b). Tazieff (1973) reported overflows which overran the main crater rim in March 1973. From this occurrence until November 2010, no further 
recorded observations were made of the southern pit filling and overflowing into the main crater in an eruptive event, or of the appearance of any fresh lava flows.

\section{Ground observations}

Ground observations began on 21 November 2010 at $\sim 1600$ hours UTC (Co-ordinated Universal Time). The team were unaware on approaching the volcano of any eruptive activity, and no visible signs, e.g. plume, could be seen on the 8-km hike up to the crater; however, on arrival, the eruption was underway (Table 1). Observations from the previous few years located the lava lake at the base of the pit, $\sim 20 \mathrm{~m}$ depth. However, the pit had filled with lava, level with the main crater floor on the western side (Figs. 1 and 2). The first overspill of lava onto the main crater floor occurred at $\sim 1650$ hours UTC (Fig. 3a). An embryonic scoria ring cone had built up around the lake, similar to that observed in 1973 (Tazieff 1973). Overspills out of the scoria cone into the pit, and occasionally on to the main crater floor, continued at approximately 2 -h intervals until $\sim 1430$ hours UTC on 22 November. Video footage indicates the lava was of low

Table 1 Summary timetable of ground observations

\begin{tabular}{|c|c|c|}
\hline Date & $\begin{array}{l}\text { Approximate } \\
\text { times (UTC) }\end{array}$ & Comment \\
\hline \multirow[t]{5}{*}{ 21st November } & 1300 & $\begin{array}{l}\text { Base of volcano, no visible signs } \\
\text { of eruption, e.g. plume }\end{array}$ \\
\hline & \multirow[t]{2}{*}{1600} & Arrival of field team at volcano \\
\hline & & $\begin{array}{l}\text { Southern pit infilled with lava; lava } \\
\text { lake was agitated with frequent } \\
\text { fire fountaining. Embryonic } \\
\text { scoria ring had built up around } \\
\text { lake }\end{array}$ \\
\hline & 1650 & $\begin{array}{l}\text { First overspill of lava onto main } \\
\text { crater floor }\end{array}$ \\
\hline & 1850 onwards & $\begin{array}{l}\text { Overspills of lava from the lake, } \\
\text { onto pit floor and occasionally } \\
\text { onto main crater floor occurred } \\
\text { at approximately } 2 \text {-h intervals }\end{array}$ \\
\hline \multirow[t]{2}{*}{ 22nd November } & \multirow[t]{2}{*}{1430} & Overspills ceased \\
\hline & & $\begin{array}{l}\text { Lava lake rose and fell by } \sim 4 \mathrm{~m} \text { on } \\
\text { a } \sim 20 \text {-min cycle with agitated } \\
\text { Strombolian activity at height of } \\
\text { cycle }\end{array}$ \\
\hline \multirow[t]{4}{*}{ 23rd November } & Overnight & $\begin{array}{l}\text { Incandescent gas jets visible, } \\
\text { some burning for several hours }\end{array}$ \\
\hline & 0400 & $\begin{array}{l}\text { Scoria ring now } \sim 4 \mathrm{~m} \text { high on } \\
\text { southern side; northern side } \\
\text { suffered partial collapse }\end{array}$ \\
\hline & 0500 & Field team left summit of Erta Ale \\
\hline & 0700 & $\begin{array}{l}\text { Field team at base of volcano; } \\
\text { distinct plume visible }\end{array}$ \\
\hline
\end{tabular}

viscosity (Supplemental Video 1). Lava flows were inflated by volatiles and thus had hollow interiors. For the remainder of the ground observation, the lake was contained within the scoria ring cone, which by 0300 hours UTC on 23 November had grown to $\sim 4 \mathrm{~m}$ high on the southern side. The lava lake level rose and fell by $\sim 4 \mathrm{~m}$ on a $\sim 20$-min cycle, with agitated Strombolian activity at the peak of each cycle. Between the peaks, activity at the lake surface was more subdued and constrained within the scoria ring with sporadic bubblebursting, rather than larger-scale fire-fountaining. On the morning of 23 November, the northern side of the scoria ring cone suffered partial collapse. Blue-green gas jets could be seen periodically at various points across the lava lake, some remaining stable for several hours. New lava flows were visible within the northern pit, together with some incandescence during the night of 21 November. After departing from the summit on 23 November, a small but distinct plume was visible above the volcano from the surrounding plain.

\section{Satellite imaging}

\section{Method}

The SEVIRI instrument is a multispectral imager aboard the second generation of Meteosat geostationary weather satellites. The Meteosat 9 satellite is positioned over $0^{\circ} \mathrm{E}, 0^{\circ} \mathrm{N}$, and the on-board SEVIRI instrument images the full Earth disc visible from this position every $15 \mathrm{~min}$ in 12 bands. Four of these bands are useful for monitoring thermal radiation from volcanic products, at wavelengths of 1.6, 3.9, 10.8 and $12.0 \mu \mathrm{m}$ (e.g. Hirn et al. 2009). The resolution of the image at the sub-satellite point is $3 \mathrm{~km}$, but this increases towards the edge of the image due to the constant angular sampling of the instrument and the curvature of the Earth, so that at Erta Ale, the resolution is approximately $4 \mathrm{~km}$ in the $\mathrm{E}-\mathrm{W}$ direction and $5 \mathrm{~km}$ in the $\mathrm{N}-\mathrm{S}$ direction (Müller 2010). Due to the stable viewing geometry of the instrument, each pixel images the same area of the Earth's surface at the same view angle in successive images, so a sequence of radiance measurements from a given pixel is directly comparable. This is in contrast with instruments on low Earth orbit satellites such as AVHRR and MODIS, where for a given volcanic feature, the observing pixel location, size and view geometry vary substantially with each acquisition, making inter-image comparisons difficult.

We acquired 9,802 Meteosat 9 SEVIRI images of the Erta Ale region between 1 October 2010 and 10 January 2011. The images were converted to radiance using the gain and offset values stored in the image headers, and the time series of radiance values for the pixel covering the Erta Ale lava lake was extracted, giving a 15-min time resolution record 
Fig. 2 Comparison of the lava levels in the south sink between (a) February 2010 and (b) 22 November 2010. The lava has filled a depth of $\sim 20 \mathrm{~m}$. The February 2010 level is similar to that observed on the 11 and 14 November (J. Wilkinson, personal communication). $\mathbf{c}-\mathbf{f}$ Cartoon cross-sections of the Erta Ale lava lake from observations by members of the field team: (c) October 2009, (d) February 2010 and $(\mathbf{e}, \mathbf{f})$ stages in the eruption of November 2010 indicating the formation of the scoria ramparts and infilling of the southern pit and sink
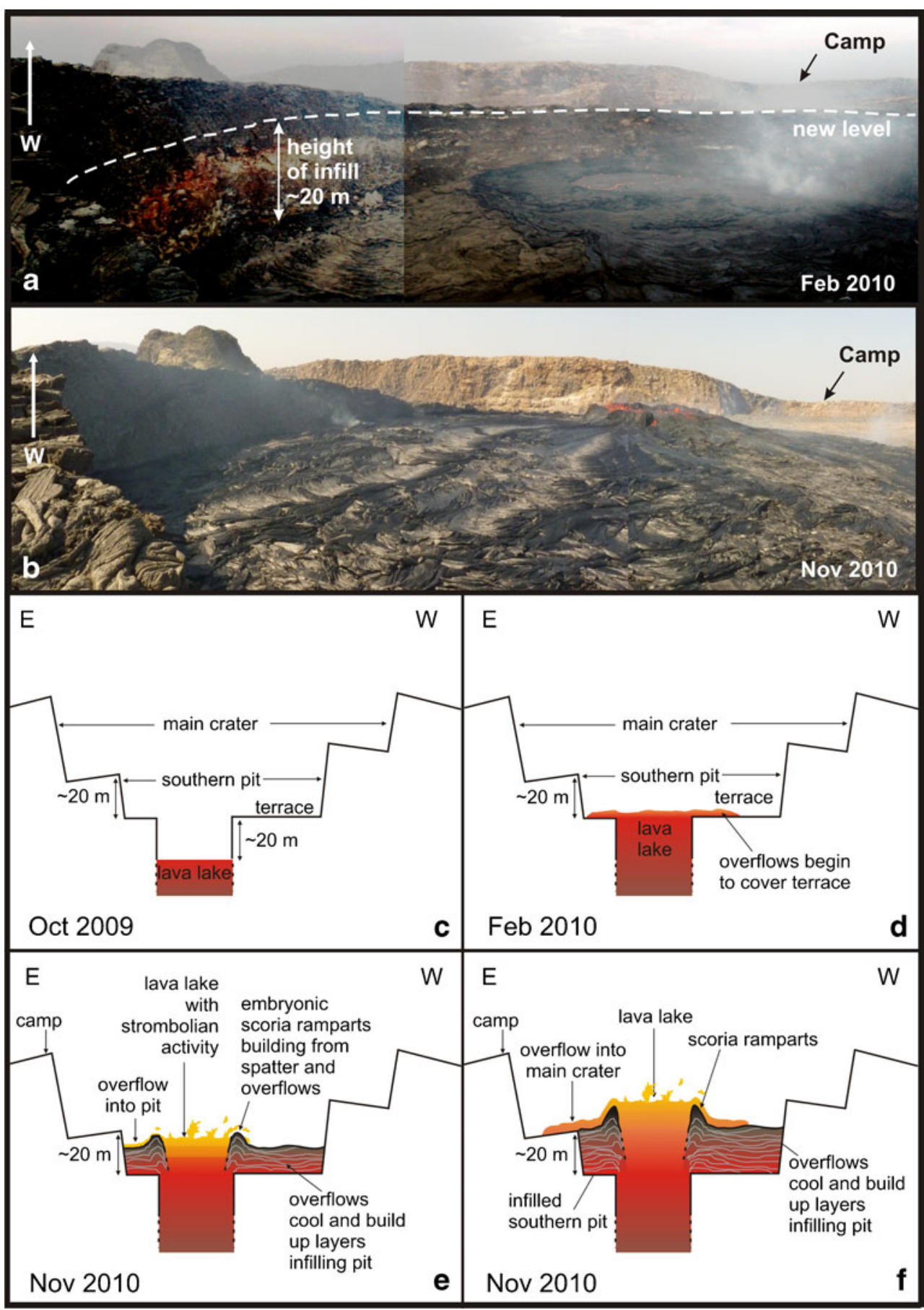

of the radiant output of the eruption. Thermal anomalies were only observed in the 3.9- $\mu \mathrm{m}$ band, consistent with the presence of a very small surface area at volcanic temperatures. Larger areas would register at the 10.8- and 12.0- $\mathrm{mm}$ bands, saturate the 3.9- $\mu \mathrm{m}$ band and, if there was enough incandescent material (e.g. cracks, fire fountains and shear zones), also register at the 1.6- $\mu \mathrm{m}$ band (Davies et al. 2010). We subtracted the radiance from a neighbouring cold pixel to obtain the excess radiance emitted by the hot volcanic material, over and above that radiated and reflected by a region with similar reflective and emissive properties at background temperatures. This gives us a time series of the thermal anomaly associated with the eruption, which we interpret qualitatively. The lava lake and background pixel do have subtle differences in radiance patterns in the absence of hot material in the lava lake pixel, and as a result, there is a regular small dip in the thermal anomaly at dawn; however, this effect is small and does not invalidate our observations, which are first order and qualitative in nature. 
Fig. 3 a Emplacement of first observed overspill (sample EA001) 1650 hours UTC on 21 November 2010. b Close-up of a section through the fresh lava showing the glassy surface, plagioclase-rich layer and vesicular core. c Close-up of the surface of the new lava. d BSE image of oscillatory-zoned plagioclase rim from sample EA001 with quenched glass matrix. e Euhedral olivine and melt inclusion from sample EA003. f Sample EA002, the underlying lava flow, which has a fine-grained groundmass. In $\mathbf{g}$ and $\mathbf{h} \mathrm{K} \alpha \mathrm{X}$-ray intensity maps in an olivine from sample EA001 are shown. g Combined phosphorous image from four spectrometers shows faint zoning throughout the crystal. h Example major element $(\mathrm{Fe})$ map shows no visible zoning

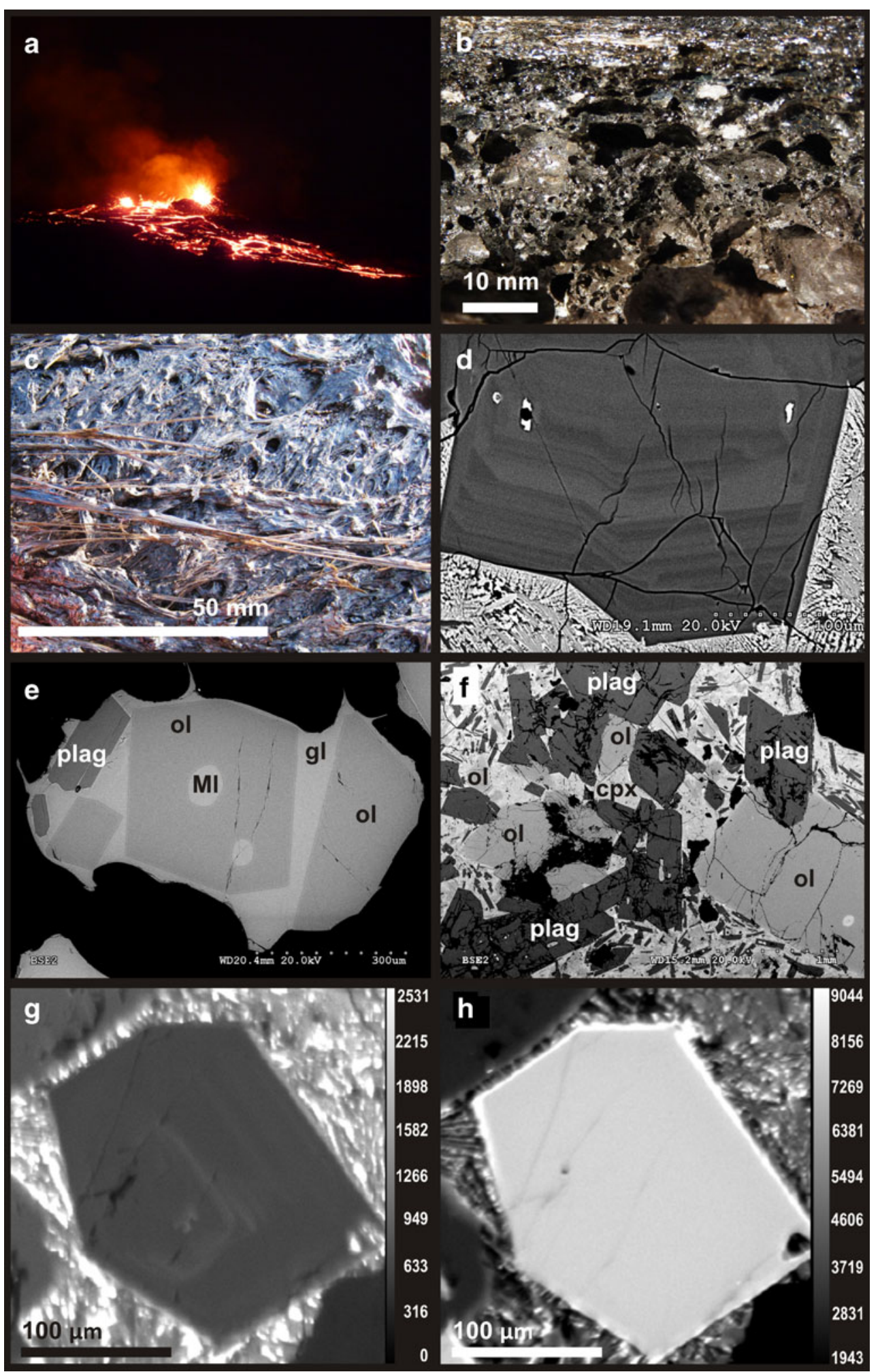

\section{Interpretation}

The Erta Ale lava lake does not typically register in any SEVIRI band, despite being frequently observed by MODIS (e.g. Ayele et al. 2007; Wright and Pilger 2008). This is a function of look angle; the MODIS instruments view the lava lake from a range of angles, while SEVIRI views from a constant angle of $\sim 42^{\circ} \mathrm{E}$, at which the lake is completely occluded from the sensor field of view by the crater rim when the lava lake is at a low stand 
(typically $\sim 20 \mathrm{~m}$ below the surface). As the lava lake level rises, or overflows onto the pit floor, more of the surface area of the lava comes into view of the sensor. This increases the measured radiance, resulting in a thermal anomaly when compared with neighbouring pixels containing no hot lava. The thermal anomaly varies over two time periods, one on a timescale of days, the other on a timescale of hours (Fig. 4).
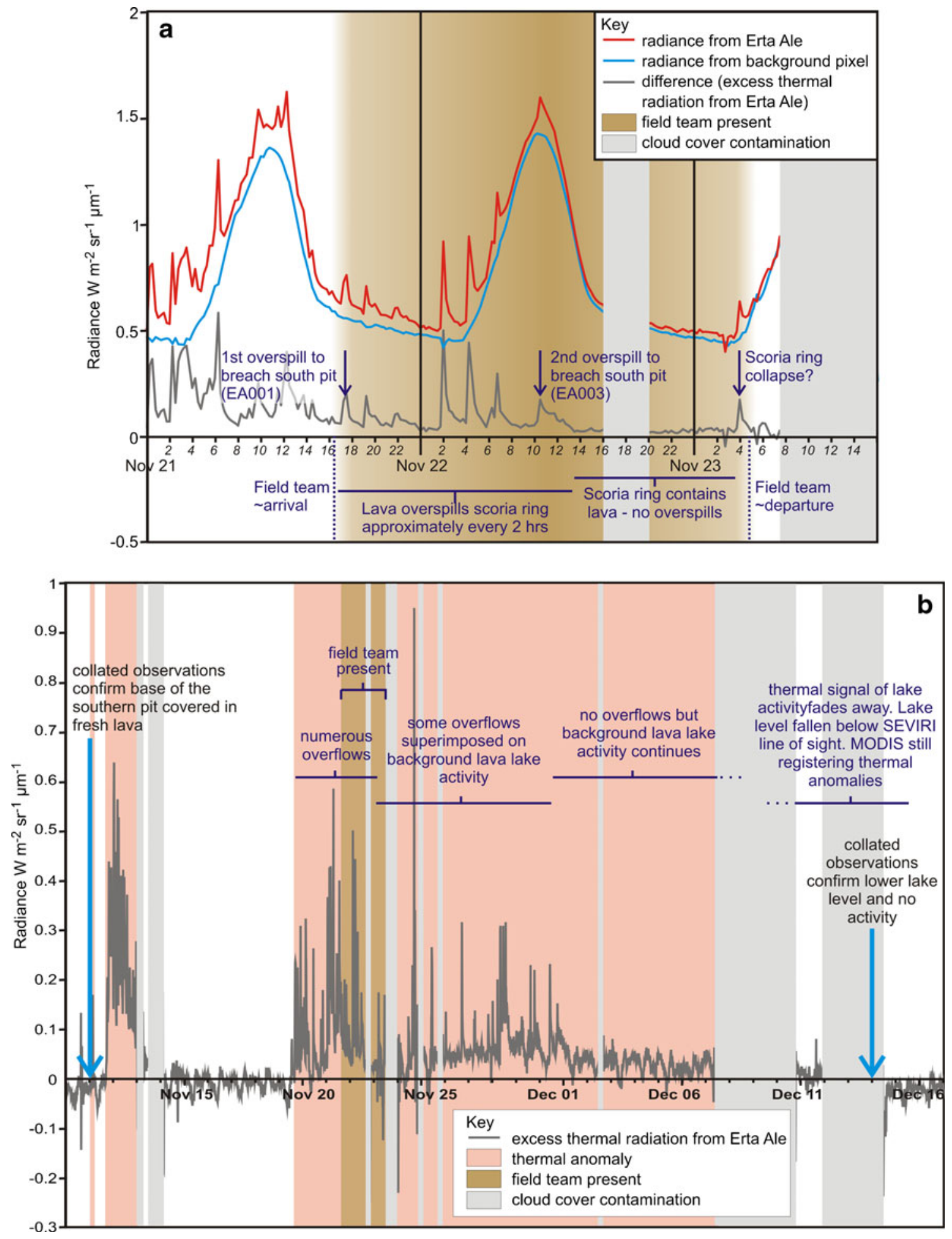

Fig. 4 SEVERI thermal signal of Erta Ale compared to contemporaneous ground observations. a Detail from when field team were present at Erta Ale showing the radiance from lava and background, and the difference, i.e. the excess thermal radiation. Time in UTC. b Overall image of the eruption showing the excess thermal radiation graph only 
The variation on a timescale of hours is characterised by sharp increases in radiance over a period of $<15 \mathrm{~min}$, followed by an exponential decay over a period of around an hour. These spikes in radiance have been correlated with lava overflows observed in the field, so we interpret the spikes as lava overflows: either initially onto the 'terrace' abutting the lake within the pit as the lake level rises or over the scoria ramparts surrounding the high stand lake, onto the new infilled surface of the pit and eventually onto the main crater floor. The rapid rise in radiance over 15 to $30 \mathrm{~min}$ associated with each spike is interpreted as the advance of the overflow; the subsequent exponential decay in radiance over a period of a few hours is the cooling of the surface. Each overflow can be considered a temporary increase in the area of the 'lava lake'. Between spikes, the background radiance from the lava lake varies little as the lava lake level remains relatively constant, which we interpret to mean the surface temperature distribution varies little.

The second thermal anomaly variance is on a timescale of days. A thermal anomaly is present during two periods (Fig. 4b). The first starts with an isolated spike in radiance at 0212 hours UTC on 11 November, which decays to the background level after about an hour. The anomaly reappears slightly later at 1557 hours UTC, peaks around midnight on 11 November and then decays to 0657 hours UTC on 13 November. This overall trend is punctuated by numerous spikes in radiance. The second period begins on 1442 hours UTC on 19 November and is marked by numerous spikes in radiance. It continues until $~ 1457$ hours UTC on 22 November. The baseline anomaly then slowly increased with markedly fewer radiance spikes to approximately midnight on 30 November. After this time, the background radiance drops to a lower level and remains at approximately this level until early morning on 7 December, when the lava lake became obscured by cloud. The thermal anomaly decays to background between 8 December and 15 December.

This pattern in the long timescale variation in the thermal anomaly could be due to changes in lava lake height (and therefore occlusion by the rim), changes in lava lake area, surface temperature distribution, Strombolian activity, overflows or renewal of activity in the solidified northern lake. Comparison with ground observations allows us to discriminate between these possibilities. From field observations, we know the period over which the lake level rose from the former position of $\sim 20 \mathrm{~m}$ below the rim to the surface, and this corresponds with a period of steadily increasing background radiance. The final area of the lava lake at high stand is also similar to the initial area $\left(\sim 500 \mathrm{~m}^{2}\right)$. We therefore infer that the long timescale variation in radiance is primarily a function of varying degrees of occlusion of a lava lake of a roughly constant area as a result of changes in lake height, rather than a variation in total lake area as a result of increasing width with height within the pit, or freezing of the margins of the lake.
Radiance spikes during the period of ground observations correlate with overflows and collapses, while a steady lowlevel radiance anomaly between spikes correlates with background lake activity. The sampling interval of $15 \mathrm{~min}$ is insufficient to resolve the observed 20-min variation in lake height. We therefore interpret the radiance spikes as overflows, as the lava lake progressively builds itself up by first episodically flooding the pit, and then constructing the scoria ramparts by successive overflows and spatter (see Fig. 2e, f).

\section{Petrology}

\section{Method}

Three samples were collected for analysis: EA001 collected from the margin of the first overflow onto the main crater floor (Figs. 1 and 3a) and sampled approximately $12 \mathrm{~h}$ after emplacement; EA002 collected from the main crater floor (most likely erupted in 1973), i.e. the flow underlying the newly erupted flows; and EA003 from the last overflow observed by the field team, collected $<1 \mathrm{~h}$ after emplacement. Whole rock major and trace elements were analysed by X-ray fluorescence (XRF) using fused glass discs and pressed powder pellets, on a PANalytical Axios-Advanced XRF spectrometer at Leicester University.

Polished thin sections were carbon-coated and imaged on a Hitachi S-3500N scanning electron microscope (SEM) prior to major element analysis using a CAMECA SX-100 electron microprobe (EMP) instrument at the University of Bristol. A 15-kV accelerating voltage, 4-nA beam current and defocused $10-\mu \mathrm{m}$ beam were used for matrix glasses and feldspars, and $20-\mathrm{kV}$ accelerating voltage, $10-\mathrm{nA}$ beam current and a focused beam $(1 \mu \mathrm{m})$ for olivines and $\mathrm{cpx}$ (clinopyroxene). A minimum of six analyses per phase were measured in each thin section.

Olivine crystals were handpicked from a crushed sample of EA003. The samples lose their glassy appearance towards the centre of the flow, and the matrix becomes dull more than $\sim 2$ $\mathrm{cm}$ depth from the surface. Phenocrysts picked for analysis were taken from the rapidly cooled, glassy upper $2 \mathrm{~cm}$ of the samples, mounted in resin and cold-cured for 2 weeks prior to polishing. Petrographic observation ensured all mounted grains contained melt inclusions (Fig. 3e). These were examined and mapped on the SEM uncoated, under variable vacuum, to minimise carbon contamination. Any melt inclusions that showed obvious signs of post-entrapment crystallisation, fractures or re-entrants were rejected. All melt inclusions were bubble-free. Eleven spot analyses from five separate melt inclusions were made, analysing for $\mathrm{CO}_{2}, \mathrm{H}_{2} \mathrm{O}$ and a number of trace elements by secondary ion mass spectrometry (SIMS) using a Cameca ims $4 \mathrm{f}$ instrument at the 
University of Edinburgh Ion Microprobe Facility. Two analyses of matrix glass were made for $\mathrm{CO}_{2}$ and $\mathrm{H}_{2} \mathrm{O}$. We used a $10-\mathrm{kV}$ (nominal) $\mathrm{O}^{-}$primary beam and 4,500 eV positive secondary ions with offset applied to reduce transmission of molecular ions. To enhance relief, grain mounts were polished with $0.3-\mu \mathrm{m}$ alumina for $30 \mathrm{~s}$ prior to gold coating. $\mathrm{CO}_{2}\left({ }^{12} \mathrm{C}^{+}\right)$was determined first at sufficient mass resolution $(\sim 1,600)$ to separate ${ }^{24} \mathrm{Mg}^{2+}$ from ${ }^{12} \mathrm{C}^{+}$because both ions have the same mass-tocharge ratio. A 5-nA primary beam, with a $15-\mu \mathrm{m}$ focused spot was used, with $50 \mathrm{eV}$ offset. Twenty-five- and two hundred fifty-micrometre lenses were activated to give a $60-\mu \mathrm{m}$ image field with field aperture No. 2 providing a $\sim 15-20-\mu \mathrm{m}$ restricted central area for analysis. Entrance slits were set at $\sim 110$ (entrance) and 112 (exit). A 2-min pre-sputter with a $15-\mu \mathrm{m}$ raster removed surface contamination prior to using a static spot for analysis. For subsequent $\mathrm{H}_{2} \mathrm{O}$ and trace element determinations, a 5-nA primary beam with $75 \mathrm{eV}$ offset and $30 \mathrm{~s}$ pre-sputter was focused in the same location as the $\mathrm{CO}_{2}$ analysis. Secondary ions of ${ }^{1} \mathrm{H}^{+},{ }^{9} \mathrm{Be}^{+},{ }^{11} \mathrm{~B}^{+},{ }^{12} \mathrm{C}^{2+},{ }^{24} \mathrm{Mg}^{2+},{ }^{26} \mathrm{Mg}^{+}$, ${ }^{30} \mathrm{Si}^{+},{ }^{42} \mathrm{Ca}^{+},{ }^{44} \mathrm{Ca}^{+},{ }^{45} \mathrm{Sc}^{+},{ }^{47} \mathrm{Ti}^{+},{ }^{88} \mathrm{Sr}^{+},{ }^{89} \mathrm{Y}^{+},{ }^{90} \mathrm{Zr}^{+},{ }^{93} \mathrm{Nb}^{+}$, ${ }^{138} \mathrm{Ba}^{+},{ }^{139} \mathrm{La}^{+},{ }^{140} \mathrm{Ce}^{+},{ }^{141} \mathrm{Pr}^{+},{ }^{143} \mathrm{Nd}^{+},{ }^{149} \mathrm{Sm}^{+},{ }^{159} \mathrm{~Tb}^{+}$, ${ }^{161} \mathrm{Dy}^{+},{ }^{165} \mathrm{Ho}^{+},{ }^{166} \mathrm{Er}^{+},{ }^{171} \mathrm{Yb}^{+},{ }^{178} \mathrm{Hf}^{+},{ }^{181} \mathrm{Ta}^{+},{ }^{232} \mathrm{Th}^{+}$ and ${ }^{238} \mathrm{U}^{+}$were collected at low mass resolution, with a $25-\mu \mathrm{m}$ image field and field aperture No. 2 providing $\sim 10 \mu \mathrm{m}$ area of analysis. Calibration and secondary standards included a range of glasses of known trace element, $\mathrm{H}_{2} \mathrm{O}$ and $\mathrm{CO}_{2}$ values (basaltic glasses of Shishkina et al. (2010), BCR2g, TPA, TPF, SRM610 and CFD), together with an olivine crystal from Erta Ale as a monitor of background consistency.

Mid-IR spectra for $\mathrm{H}_{2} \mathrm{O}$ and $\mathrm{CO}_{2}$ were obtained at Bristol using a Nicolet Nexus 670 FTIR spectrometer with an IR PLAN microscope attachment, Globar source, $\mathrm{KBr}$ beamsplitter and MCT detector (512 scans at $8-\mathrm{cm}^{-1}$ resolution). Double-polished plates of around $50-\mu \mathrm{m}$ thickness were prepared and measured with Mitutoyo Digital Micrometer to $\pm 1 \mu \mathrm{m}$. This thickness allowed an $80-\mu \mathrm{m}$ beam to pass through the melt inclusions (or the matrix glass) uninterrupted. Spectra were compared to a volatile-free basalt to estimate peak heights, and these were converted to concentrations using extinction coefficients of $63 \mathrm{~L} \mathrm{~mol}^{-1} \mathrm{~cm}^{-1}$ for water at $3,550 \mathrm{~cm}^{-1}$ and $375 \mathrm{Lmol}^{-1} \mathrm{~cm}^{-1}$ for one of the carbonate doublet peaks at $1,375 \mathrm{~cm}^{-1}$ (from Dixon et al. (1988) and Fine and Stolper (1986), respectively). The errors in the measured IR peak intensities (due to background subtraction), the extinction coefficient, the thickness measurement and the density estimate lead to an uncertainty of about $\pm 20 \%$ for water and $\pm 35 \%$ for $\mathrm{CO}_{2}$ in the inclusions. For the matrix glass, the $\mathrm{CO}_{2}$ peak is not visible, suggesting it is below the detection limit of $\sim 50 \mathrm{ppm}$ for this sample thickness.
Major elements were determined quantitatively by EMPA on the same melt inclusions previously analysed by SIMS and on phenocryst minerals. High precision $\mathrm{S}$ and $\mathrm{Cl}$ concentration were also determined for matrix glass, one melt inclusion (J), and two small, previously unanalysed melt inclusions using two spectrometers for each element to increase total counts. The peak count was $120 \mathrm{~s}$ on each spectrometer. The spectrometers were calibrated using BCR2 [Basaltic glass, Columbia River (Wilson 1997)]. Oxygen was calculated by stoichiometry, and weight percent oxide totals for $\mathrm{SO}_{2}$ are reported. $\mathrm{K} \alpha \mathrm{X}$-ray intensity maps for phosphorous, $\mathrm{Ca}$ and $\mathrm{Fe}$ in olivine phenocrysts in EA001 were obtained in two stages. The first mapped $\mathrm{P}$ and Fe with a $256 \times 256$ pixel image and dwell time of $100 \mathrm{~ms}$ per pixel. A second run at higher resolution used dwell times of $200 \mathrm{~ms}$ per pixel and a $512 \times$ 512 pixel image, imaging $\mathrm{P}$ and $\mathrm{Ca}$. For both runs, a beam current of $400 \mathrm{nA}$, an accelerating voltage of $20 \mathrm{kV}$ and beam diameter of $1 \mu \mathrm{m}$ was used. Phosphorous was mapped on four of the five spectrometers in both cases, and the final images were summed.

\section{Results}

The lavas are porphyritic ( $20 \%$ by volume) and vesiclerich (up to $60 \%$ volume in EA003, calculated by point counting; see Fig. 3b), and can be classified chemically as transitional basalts (Irvine and Baragar 1971). There are surprisingly few published chemical analyses of basalts from Erta Ale volcano. To our knowledge, the only published values come from Barberi et al. (1974) and Bizouard et al. (1980) who present only major elements on two samples from Erta Ale volcano (one from the summit crater wall, and one from a western flank fissure) and Barrat et al. (1998) who present major and trace elements of four samples from the volcano. The 2010 lavas (EA001 and EA003) are olivine-normative, whereas the older underlying lava (EA002: most likely from the 1973 eruption) is quartznormative (Table 2). The sample taken from the underlying lava has a higher silica content than the 2010 samples, comparable to the Erta Ale sample (F12) analysed by Barberi et al. (1974) from the main crater wall. This suggests the recent input to the system of less evolved but chemically similar magma. EA002 also shows significant differences in texture (Fig. 3f); a crystalline groundmass with large glomerocrysts of plagioclase, cpx and olivine, compared to the quenched glass matrix and discrete euhedral crystals found in EA001 and 3 (Fig. 3d, e). The silica contents of the 2010 samples are comparable $(<50$ wt. $\%)$ to those of samples analysed by Barrat et al. (1998), although the exact locality of those samples has not been ascertained. The mineral assemblage in the 2010 samples is plagioclase + clinopyroxene + olivine. No oxides or other accessory phases are present in any sample. Euhedral plagioclase phenocrysts, up to $4 \mathrm{~mm}$, show 
Table 2 Whole rock XRF analyses

\begin{tabular}{|c|c|c|c|}
\hline Sample & EA001 & EA002 & EA003 \\
\hline$n$ & 1 & 1 & 1 \\
\hline $\mathrm{SiO}_{2}{ }^{\mathrm{a}}$ (wt.\%) & 48.85 & 51.36 & 49.12 \\
\hline $\mathrm{TiO}_{2}$ & 1.96 & 2.13 & 1.95 \\
\hline $\mathrm{Al}_{2} \mathrm{O}_{3}$ & 16.57 & 14.88 & 16.56 \\
\hline $\mathrm{Fe}_{2} \mathrm{O}_{3}{ }^{\mathrm{T}}$ & 10.77 & 11.38 & 10.77 \\
\hline $\mathrm{MnO}$ & 0.17 & 0.17 & 0.17 \\
\hline $\mathrm{MgO}$ & 6.04 & 5.61 & 6.13 \\
\hline $\mathrm{CaO}$ & 12.41 & 10.86 & 12.40 \\
\hline $\mathrm{Na}_{2} \mathrm{O}$ & 2.66 & 2.62 & 2.65 \\
\hline $\mathrm{K}_{2} \mathrm{O}$ & 0.50 & 0.70 & 0.49 \\
\hline $\mathrm{P}_{2} \mathrm{O}_{5}$ & 0.27 & 0.30 & 0.27 \\
\hline $\mathrm{SO}_{3}$ & b.d. & 0.42 & b.d. \\
\hline LOI & -0.37 & 0.34 & -0.39 \\
\hline Total & 99.81 & 100.77 & 100.10 \\
\hline $\mathrm{Rb}$ & 11 & 18 & 12 \\
\hline $\mathrm{Sr}$ & 310 & 318 & 315 \\
\hline $\mathrm{Y}$ & 28 & 30 & 29 \\
\hline $\mathrm{Zr}$ & 159 & 198 & 163 \\
\hline $\mathrm{Pb}$ & 2 & 4 & 2 \\
\hline Th & 3 & 3 & 2 \\
\hline $\mathrm{U}$ & 2 & 1 & 2 \\
\hline $\mathrm{Ga}$ & 19 & 19 & 19 \\
\hline $\mathrm{Zn}$ & 76 & 78 & 77 \\
\hline $\mathrm{Cu}$ & 106 & 96 & 109 \\
\hline $\mathrm{Ni}$ & 47 & 41 & 52 \\
\hline Co & 41 & 36 & 42 \\
\hline $\mathrm{Cr}$ & 128 & 142 & 127 \\
\hline V & 287 & 288 & 292 \\
\hline $\mathrm{Sc}$ & 37 & 34 & 38 \\
\hline $\mathrm{Ba}$ & 118 & 190 & 119 \\
\hline $\mathrm{La}$ & 18 & 21 & 20 \\
\hline $\mathrm{Ce}$ & 51 & 48 & 46 \\
\hline $\mathrm{Nd}$ & 26 & 24 & 26 \\
\hline Cs & b.d. & b.d. & b.d. \\
\hline
\end{tabular}

$n$ denotes number of analyses, superscript " $T$ " denotes total iron

b.d. below detection level

${ }^{a}$ Major element analysis-XRF, University of Leicester

normal zoning from core to rim, but within some rims, oscillatory zoning is present (Fig. 3d), and there is evidence of resorption between some of the zones. Plagioclase is the dominant phenocryst comprising $\sim 90 \%$ of all phenocrysts. It is also found as small inclusions in both clinopyroxene and olivine, with anorthite $(\mathrm{An})$ content in the range $\mathrm{An}_{83-74}$. Anorthite content in plagioclase cores from the 2010 lavas (Table 3 ) is $\mathrm{An}_{85-69}$; the range within an individual core is more restricted, e.g. $\mathrm{An}_{85-82}, \mathrm{An}_{71-69}$. Within the zoned rims, An values show a wide range from $\mathrm{An}_{80-66}$, with the higher
An values found in those phenocrysts with higher An cores. A very similar range of $A n$ contents is found in EA002 $\left(\mathrm{An}_{82-75}\right.$ in cores, $\mathrm{An}_{76-66}$ in rims). Plagioclase groundmass microlites are only present in EA002 and range from $\mathrm{An}_{71-63}$. Clinopyroxene crystals are subhedral, small $(<1 \mathrm{~mm})$ augites, often forming glomerocrysts with plagioclase (Table 3$)$. Mg\# (100× molar $\left.\mathrm{Mg} /\left[\mathrm{Mg}+\mathrm{Fe}_{\text {tot }}\right]\right)$ values range from 84 to 72 . One tiny $(\sim 50 \mu \mathrm{m})$ euhedral clinopyroxene inclusion $(\mathrm{Mg} \# 82)$ was found in an olivine. Olivines are euhedral with $\mathrm{Fo}_{84-78}$ content in phenocrysts and $\mathrm{Fo}_{80-73}$ in rims and EA002 groundmass (Table 3).

The raw analyses of the melt inclusions indicate compositions that are close to those of the matrix glass, suggesting limited post-entrapment modification (Table 4). Using an olivine-melt $\mathrm{Kd}_{\mathrm{Fe}-\mathrm{Mg}}$ of 0.28 , we estimate that postentrapment crystallisation is less than $6 \%$, which would have negligible effect on the measured volatile or trace element contents. It is much more difficult to make a correction for open-system processes such as $\mathrm{Fe}$ diffusion through the host olivine. Consequently, the MI data have not been corrected for post-entrapment processes, and all data are reported as analysed. The $\mathrm{H}_{2} \mathrm{O}$ content of the five inclusions ranges from 867 to $1,329 \mathrm{ppm} ; \mathrm{CO}_{2}$ contents range from 33 to 194 ppm (Table 4). Multiple analyses of single melt inclusions show them to be homogeneous for $\mathrm{H}_{2} \mathrm{O}$ and $\mathrm{CO}_{2}$. Matrix glass

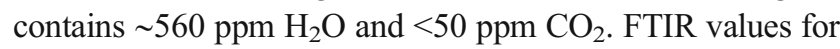
$\mathrm{CO}_{2}$ agree with those determined by SIMS $(<50 \mathrm{ppm}$ in matrix glass and 94-136 ppm in melt inclusions). FTIR $\mathrm{H}_{2} \mathrm{O}$ values are systematically higher than SIMS, with melt inclusion values of 1,700-2,000 and 1,700 ppm in matrix glass). The source of this systematic offset is unknown, but may originate in uncertainty in the FTIR extinction coefficients or ion-yield difference for ${ }^{1} \mathrm{H}$ between Erta Ale glasses and the standards used. $\mathrm{SO}_{2}$ contents of melt inclusions, measured by EMP (Table 4), are 247-419 ppm; chlorine contents are 158-368 ppm. Average $\mathrm{SO}_{2}$ and $\mathrm{Cl}$ values from 25 analyses in matrix glass were determined as 91 and 195 ppm, respectively.

Temperatures were calculated using various mineral/liquid thermometers with an average of $\sim 1,150^{\circ} \mathrm{C}$ from all methods (Table 5). Pre-eruptive temperatures derived from crystal rim/ matrix combinations in plagioclase/liquid (Eq. 24a, Putirka 2008) are in the range $1,171-1,180{ }^{\circ} \mathrm{C}$, clinopyroxene/liquid (Putirka et al. 1996) temperatures are $1,148-1,175^{\circ} \mathrm{C}$, and olivine/liquid temperatures are $1,151-1,158^{\circ} \mathrm{C}$ (Putirka 2008) and $1,157^{\circ} \mathrm{C}$ (Beattie 1993). Temperatures derived from melt inclusion/host crystal combinations using the method of Putirka (2008) are in the range $1,094-1,148{ }^{\circ} \mathrm{C}$, with similar temperatures $\left(1,104-1,148{ }^{\circ} \mathrm{C}\right)$ obtained from the method of Beattie (1993).

Volatile saturation pressures were calculated using the method of VolatileCalc (Newman and Lowenstern 2002) and range from 7 to $40 \mathrm{MPa}$. To convert these pressures to 
Table 3 Representative phenocryst analyses b.d. below detection level

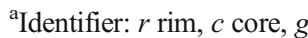
groundmass, $i$ inclusion

${ }^{\mathrm{b}}$ EMPA analysis (wt.\% oxide) University of Bristol

${ }^{\mathrm{c}} \mathrm{FeO}^{\mathrm{T}}$ is total $\mathrm{Fe}$

${ }^{\mathrm{d}} \mathrm{Fe}$ ratio is calculated using the method of Schumacher (1997)

${ }^{\mathrm{e}} \mathrm{Mg}$ number $100 \times$ wt.\% $\% \mathrm{MgO} /$ $\left(\mathrm{MgO}+\mathrm{FeO}^{\mathrm{T}}\right)$

\begin{tabular}{|c|c|c|c|c|c|c|c|}
\hline & Sample & EA001 & EA001 & EA002 & EA002 & EA003 & EA003 \\
\hline \multirow[t]{12}{*}{ Plagioclase } & Identifier $^{\mathrm{a}}$ & $\mathrm{c}$ & $\mathrm{r}$ & $\mathrm{g}$ & $\mathrm{c}$ & $\mathrm{c}$ & $\mathrm{r}$ \\
\hline & $\mathrm{SiO}_{2}{ }^{\mathrm{b}}$ & 47.10 & 47.73 & 51.30 & 48.62 & 47.41 & 47.89 \\
\hline & $\mathrm{Al}_{2} \mathrm{O}_{3}$ & 32.96 & 31.48 & 29.76 & 31.11 & 31.80 & 31.44 \\
\hline & $\mathrm{FeO}^{\mathrm{Tc}}$ & 0.57 & 0.57 & 0.72 & 0.54 & 0.50 & 0.59 \\
\hline & $\mathrm{MgO}$ & 0.15 & 0.21 & 0.17 & 0.22 & 0.16 & 0.18 \\
\hline & $\mathrm{CaO}$ & 16.60 & 15.53 & 13.34 & 15.24 & 15.77 & 15.64 \\
\hline & $\mathrm{Na}_{2} \mathrm{O}$ & 1.90 & 2.54 & 3.59 & 2.67 & 2.28 & 2.35 \\
\hline & $\mathrm{K}_{2} \mathrm{O}$ & b.d. & 0.11 & 0.17 & b.d. & 0.10 & 0.09 \\
\hline & Total & 99.27 & 98.16 & 99.05 & 98.39 & 98.03 & 98.17 \\
\hline & An & 82.84 & 76.64 & 66.54 & 75.96 & 78.81 & 78.20 \\
\hline & $\mathrm{Ab}$ & 17.16 & 22.73 & 32.43 & 24.04 & 20.62 & 21.26 \\
\hline & Or & 0.00 & 0.63 & 1.03 & 0.00 & 0.57 & 0.54 \\
\hline \multirow[t]{17}{*}{ Clinopyroxene } & Identifier $^{\mathrm{a}}$ & $\mathrm{c}$ & $\mathrm{r}$ & $\mathrm{c}$ & $\mathrm{g}$ & $\mathrm{c}$ & $\mathrm{r}$ \\
\hline & $\mathrm{SiO}_{2}{ }^{\mathrm{b}}$ & 52.01 & 51.59 & 51.25 & 50.29 & 53.26 & 51.30 \\
\hline & $\mathrm{TiO}_{2}$ & 0.76 & 0.89 & 0.93 & 1.36 & 0.64 & 0.91 \\
\hline & $\mathrm{Al}_{2} \mathrm{O}_{3}$ & 2.62 & 2.91 & 2.99 & 3.69 & 1.85 & 2.52 \\
\hline & $\mathrm{FeO}^{\mathrm{Tc}}$ & 5.90 & 6.45 & 6.43 & 8.14 & 6.60 & 7.18 \\
\hline & $\mathrm{MnO}$ & 0.16 & 0.17 & 0.16 & 0.21 & 0.16 & 0.19 \\
\hline & $\mathrm{MgO}$ & 16.29 & 16.16 & 16.02 & 15.65 & 17.04 & 16.49 \\
\hline & $\mathrm{CaO}$ & 21.44 & 21.09 & 20.96 & 19.84 & 20.77 & 20.26 \\
\hline & $\mathrm{Na}_{2} \mathrm{O}$ & 0.21 & 0.34 & 0.31 & 0.29 & 0.28 & 0.19 \\
\hline & $\mathrm{Cr}_{2} \mathrm{O}_{3}$ & 0.33 & 0.29 & 0.31 & 0.19 & 0.18 & 0.14 \\
\hline & Total & 99.72 & 99.88 & 99.35 & 99.66 & 100.79 & 99.17 \\
\hline & $\mathrm{Fe}^{3+\mathrm{d}}$ & 0.02 & 0.05 & 0.04 & 0.05 & 0.02 & 0.04 \\
\hline & $\mathrm{Fe}^{2+\mathrm{d}}$ & 0.16 & 0.15 & 0.16 & 0.20 & 0.18 & 0.18 \\
\hline & En & 47 & 46 & 46 & 45 & 48 & 47 \\
\hline & Fs & 9 & 10 & 10 & 13 & 10 & 11 \\
\hline & Wo & 44 & 43 & 43 & 41 & 42 & 42 \\
\hline & $\mathrm{Mg} \#^{\mathrm{e}}$ & 83 & 82 & 82 & 77 & 82 & 80 \\
\hline \multirow[t]{13}{*}{ Olivine } & Identifier $^{\mathrm{a}}$ & $\mathrm{c}$ & r & $\mathrm{c}$ & g & $\mathrm{c}$ & $\mathrm{c}$ \\
\hline & $\mathrm{SiO}_{2}^{\mathrm{b}}$ & 38.77 & 38.92 & 40.25 & 38.14 & 38.81 & 38.85 \\
\hline & $\mathrm{TiO}_{2}$ & b.d. & 0.04 & b.d. & 0.05 & b.d. & 0.02 \\
\hline & $\mathrm{Al}_{2} \mathrm{O}_{3}$ & b.d. & b.d. & 0.05 & b.d. & 0.04 & 0.04 \\
\hline & $\mathrm{FeO}^{\mathrm{Tc}}$ & 19.33 & 20.88 & 15.62 & 24.37 & 20.42 & 19.90 \\
\hline & $\mathrm{MnO}$ & 0.30 & 0.32 & 0.23 & 0.37 & 0.32 & 0.32 \\
\hline & $\mathrm{MgO}$ & 41.23 & 40.48 & 44.41 & 36.69 & 40.27 & 40.27 \\
\hline & $\mathrm{CaO}$ & 0.36 & 0.37 & 0.30 & 0.38 & 0.37 & 0.38 \\
\hline & Total & 99.99 & 101.01 & 100.86 & 100.00 & 100.23 & 99.79 \\
\hline & Fo & 78.9 & 77.3 & 83.3 & 72.6 & 77.6 & 78.0 \\
\hline & $\mathrm{Fa}$ & 20.8 & 22.4 & 16.4 & 27.0 & 22.1 & 21.6 \\
\hline & $\mathrm{Tp}$ & 0.3 & 0.3 & 0.2 & 0.4 & 0.4 & 0.4 \\
\hline & $\mathrm{Mg} \#^{\mathrm{e}}$ & 79 & 78 & 84 & 73 & 78 & 78 \\
\hline
\end{tabular}

depth, we have assumed a crustal density of $2,850 \mathrm{kgm}^{-3}$ based on gravity studies in the Main Ethiopian Rift (e.g. Mahatsente et al. 1999). The calculated saturation depths are shallow: 0.2 to $1.4 \mathrm{~km}$.

Trace element contents of melt inclusions (Table 4) are broadly similar to those of the host lavas with slightly elevated incompatible elements and lower compatible elements, consistent with $\sim 20 \%$ crystallisation, i.e. the phenocryst content. Incompatible elements, e.g. Ba, are positively correlated with $\mathrm{H}_{2} \mathrm{O}$ and negatively correlated with $\mathrm{CO}_{2}$, despite a relatively small variation in all parameters (Fig. 6). The trace element content of the underlying lava (EA002) differs from the 2010 
Table 4 Averaged melt inclusion major, trace and volatile analyses with host olivine analyses, and matrix glass majors and volatiles

\begin{tabular}{|c|c|c|c|c|c|c|c|c|c|c|c|c|c|}
\hline \multirow{2}{*}{$\begin{array}{l}\text { Sample } \\
\text { Host/MI }\end{array}$} & \multicolumn{2}{|l|}{ EA003 } & \multicolumn{2}{|l|}{ EA003 } & \multicolumn{2}{|l|}{ EA003 } & \multicolumn{2}{|l|}{ EA003 } & \multicolumn{2}{|l|}{ EA003 } & \multirow{2}{*}{$\begin{array}{l}\text { EA003b } \\
3\end{array}$} & \multirow{2}{*}{$\begin{array}{l}\text { EA003b } \\
6\end{array}$} & \multirow{2}{*}{$\begin{array}{l}\text { EA003 } \\
\text { Matrix }\end{array}$} \\
\hline & Olivine & G & Olivine & $\mathrm{H}$ & Olivine & I & Olivine & $\mathrm{J}$ & Olivine & $\mathrm{L}$ & & & \\
\hline$n$ & 2 & 4 & 2 & 4 & 2 & 4 & 2 & 5 & 2 & 4 & & & 5 \\
\hline $\mathrm{SiO}_{2}(\mathrm{wt} \%)^{\mathrm{a}}$ & 38.77 & 49.17 & 39.11 & 49.29 & 39.19 & 49.32 & 39.07 & 49.88 & 38.32 & 49.28 & & & 49.26 \\
\hline $\mathrm{TiO}_{2}$ & 0.01 & 2.42 & 0.00 & 2.38 & 0.02 & 2.42 & 0.00 & 2.30 & 0.01 & 2.50 & & & 2.41 \\
\hline $\mathrm{Al}_{2} \mathrm{O}_{3}$ & 0.02 & 13.84 & 0.02 & 13.94 & 0.00 & 13.84 & 0.02 & 14.18 & 0.04 & 13.75 & & & 13.86 \\
\hline $\mathrm{FeO}$ & 19.16 & 11.49 & 19.36 & 11.30 & 19.90 & 11.80 & 18.55 & 10.94 & 20.15 & 12.13 & & & 11.36 \\
\hline $\mathrm{MnO}$ & 0.32 & 0.23 & 0.31 & 0.21 & 0.33 & 0.21 & 0.29 & 0.22 & 0.31 & 0.23 & & & 0.27 \\
\hline $\mathrm{MgO}$ & 41.13 & 5.60 & 40.75 & 6.15 & 40.84 & 4.79 & 41.43 & 6.02 & 40.29 & 5.40 & & & 6.27 \\
\hline $\mathrm{CaO}$ & 0.35 & 11.96 & 0.33 & 11.74 & 0.35 & 12.43 & 0.33 & 11.75 & 0.35 & 11.75 & & & 11.33 \\
\hline $\mathrm{Na}_{2} \mathrm{O}$ & 0.00 & 2.83 & 0.00 & 2.71 & 0.00 & 2.77 & 0.00 & 2.86 & 0.00 & 2.94 & & & 2.97 \\
\hline $\mathrm{K}_{2} \mathrm{O}$ & & 0.58 & & 0.55 & & 0.55 & & 0.57 & & 0.59 & & & 0.63 \\
\hline $\mathrm{P}_{2} \mathrm{O}_{5}$ & 0.00 & 0.51 & 0.02 & 0.39 & 0.02 & 0.36 & 0.00 & 0.38 & 0.00 & 0.39 & & & 0.37 \\
\hline $\mathrm{F}$ & & b.d. & & b.d. & & b.d. & & b.d. & & b.d. & & & b.d. \\
\hline Total & & 98.63 & & 98.66 & & 98.48 & & 99.09 & & 98.98 & & & 98.72 \\
\hline Forsterite & 79.01 & & 78.69 & & 78.26 & & 79.68 & & 77.83 & & & & \\
\hline Fayalite & 20.64 & & 20.97 & & 21.38 & & 20.00 & & 21.83 & & & & \\
\hline Tephroite & 0.34 & & 0.34 & & 0.36 & & 0.32 & & 0.34 & & & & \\
\hline $\mathrm{Mg} \#^{\mathrm{b}}$ & 79.29 & & 78.96 & & 78.54 & & 79.93 & & 78.10 & & & & \\
\hline SIMS $(n)$ & & 2 & & 3 & & 3 & & 2 & & 1 & & & 2 \\
\hline $\mathrm{H}_{2} \mathrm{O}(\mathrm{ppm})^{\mathrm{c}}$ & & 1329 & & 867 & & 1118 & & 1035 & & 910 & & & 559 \\
\hline uncertainty $^{\mathrm{d}}$ & & 37 & & 24 & & 32 & & 34 & & 20 & & & 20 \\
\hline $\mathrm{CO}_{2}(\mathrm{ppm})^{\mathrm{c}}$ & & 33 & & 194 & & 82 & & 124 & & 130 & & & $<50$ \\
\hline uncertainty $^{\mathrm{d}}$ & & 1 & & 6 & & 2 & & 4 & & 4 & & & \\
\hline FTIR $(n)$ & & & & & & 2 & & 2 & & & & & 2 \\
\hline $\mathrm{H}_{2} \mathrm{O}(\mathrm{ppm})^{\mathrm{e}}$ & & & & & & 2000 & & 1700 & & & & & 1700 \\
\hline uncertainty $^{\mathrm{f}}$ & & & & & & 400 & & 340 & & & & & 340 \\
\hline $\mathrm{CO}_{2}(\mathrm{ppm})^{\mathrm{e}}$ & & & & & & 94 & & 136 & & & & & $<50$ \\
\hline uncertainty $^{\mathrm{f}}$ & & & & & & 33 & & 50 & & & & & \\
\hline$n$ & & & & & & & & 4 & & & 1 & 1 & 25 \\
\hline $\mathrm{SO}_{2}(\mathrm{ppm})^{\mathrm{a}}$ & & & & & & & & 419 & & & 308 & 247 & 91 \\
\hline $\mathrm{sd}(1 \sigma)^{\mathrm{e}}$ & & & & & & & & 67 & & & & & \\
\hline $\mathrm{Cl}(\mathrm{ppm})^{\mathrm{a}}$ & & & & & & & & 368 & & & 158 & 251 & 195 \\
\hline $\operatorname{sd}(1 \sigma)^{\mathrm{e}}$ & & & & & & & & 148 & & & & & \\
\hline $\mathrm{T}\left({ }^{\circ} \mathrm{C}\right)^{\mathrm{g}}$ & & 1174 & & 1169 & & 1179 & & 1175 & & 1182 & & & \\
\hline $\mathrm{P}(\mathrm{Mpa})^{\mathrm{h}}$ & & 7 & & 40 & & 16 & & 25 & & 27 & & & \\
\hline Depth $(\mathrm{km})^{\mathrm{i}}$ & & 0.2 & & 1.4 & & 0.6 & & 0.9 & & 0.9 & & & \\
\hline $\mathrm{n}$ & & 2 & & 3 & & 3 & & 2 & & 1 & & & \\
\hline $\mathrm{Be}(\mathrm{ppm})^{\mathrm{j}}$ & & 1 & & 1 & & 1 & & 1 & & 1 & & & \\
\hline B & & 4 & & 4 & & 4 & & 4 & & 3 & & & \\
\hline $\mathrm{Sc}$ & & 45 & & 45 & & 48 & & 45 & & 45 & & & \\
\hline $\mathrm{Sr}$ & & 330 & & 334 & & 355 & & 327 & & 340 & & & \\
\hline $\mathrm{Y}$ & & 41 & & 41 & & 43 & & 40 & & 40 & & & \\
\hline $\mathrm{Zr}$ & & 221 & & 210 & & 218 & & 213 & & 219 & & & \\
\hline $\mathrm{Nb}$ & & 38 & & 34 & & 36 & & 34 & & 39 & & & \\
\hline $\mathrm{Ba}$ & & 166 & & 153 & & 164 & & 156 & & 174 & & & \\
\hline $\mathrm{La}$ & & 33 & & 31 & & 35 & & 33 & & 32 & & & \\
\hline $\mathrm{Ce}$ & & 65 & & 64 & & 70 & & 64 & & 65 & & & \\
\hline $\operatorname{Pr}$ & & 8 & & 8 & & 8 & & 8 & & 8 & & & \\
\hline
\end{tabular}


Table 4 (continued)

\begin{tabular}{|c|c|c|c|c|c|c|c|c|c|c|c|c|c|}
\hline \multirow{2}{*}{$\begin{array}{l}\text { Sample } \\
\text { Host/MI }\end{array}$} & \multicolumn{2}{|l|}{ EA003 } & \multicolumn{2}{|l|}{ EA003 } & \multicolumn{2}{|l|}{ EA003 } & \multicolumn{2}{|l|}{ EA003 } & \multicolumn{2}{|l|}{ EA003 } & \multirow{2}{*}{$\begin{array}{l}\text { EA003b } \\
3\end{array}$} & \multirow{2}{*}{$\begin{array}{l}\text { EA003b } \\
6\end{array}$} & \multirow{2}{*}{$\begin{array}{l}\text { EA003 } \\
\text { Matrix }\end{array}$} \\
\hline & Olivine & G & Olivine & $\mathrm{H}$ & Olivine & I & Olivine & $\mathrm{J}$ & Olivine & $\mathrm{L}$ & & & \\
\hline $\mathrm{Nd}$ & & 26 & & 25 & & 27 & & 26 & & 25 & & & \\
\hline $\mathrm{Sm}$ & & 8 & & 7 & & 8 & & 8 & & 8 & & & \\
\hline $\mathrm{Tb}$ & & 1 & & 1 & & 1 & & 1 & & 1 & & & \\
\hline Dy & & 6 & & 6 & & 7 & & 5 & & 6 & & & \\
\hline Но & & 1 & & 1 & & 1 & & 1 & & 1 & & & \\
\hline Er & & 4 & & 4 & & 4 & & 4 & & 4 & & & \\
\hline $\mathrm{Yb}$ & & 3 & & 3 & & 3 & & 3 & & 3 & & & \\
\hline $\mathrm{Lu}$ & & 0 & & 1 & & 0 & & 1 & & 1 & & & \\
\hline $\mathrm{Hf}$ & & 4 & & 4 & & 4 & & 4 & & 4 & & & \\
\hline $\mathrm{Ta}$ & & 2 & & 2 & & 2 & & 2 & & 2 & & & \\
\hline Th & & 3 & & 4 & & 4 & & 4 & & 3 & & & \\
\hline $\mathrm{U}$ & & 1 & & 1 & & 1 & & 1 & & 1 & & & \\
\hline
\end{tabular}

$n$ number of analyses, b.d. below detection level, blank space no analysis, host phenocryst hosting the inclusion, identifier melt inclusion

${ }^{a}$ Averaged major element analysis-EMPA, University of Bristol

${ }^{\mathrm{b}} \mathrm{Mg}$ number $100 \times$ wt. $\% \mathrm{MgO} /\left(\mathrm{MgO}+\mathrm{FeO}^{\mathrm{T}}\right)$

${ }^{\mathrm{c}}$ Averaged SIMS analysis, University of Edinburgh

${ }^{\mathrm{d}}$ Average uncertainty as determined by full propagation of counting statistics, instrument background and calibration working curve

${ }^{\mathrm{e}}$ FTIR, University of Bristol

${ }^{\mathrm{f}}$ IR propagated uncertainty-see text for error source

${ }^{\mathrm{g}}$ Temperature in degrees Celsius using the method of Putirka (2008). Calibration error $\pm 45^{\circ} \mathrm{C}$,

${ }^{\mathrm{h}}$ Pressure in MPa using the method of Newman and Lowenstern

${ }^{\mathrm{i}}$ Depth calculated from $\mathrm{P}$ assuming a crustal density of $\sim 2,850 \mathrm{kgm}^{-3}$. Depth is depth below surface.

${ }^{\mathrm{j}}$ Trace elements determined by SIMS analysis at the University of Edinburgh

lavas, most noticeable in the elevated levels of incompatible $\mathrm{Ba}$ which may reflect the greater crystallinity of this sample.

$\mathrm{K} \alpha \mathrm{X}$-ray mapping of an olivine phenocryst from EA001 indicates homogeneity throughout the crystal for major elements such as Fe (Fig. 3h). However, feint concentric, oscillatory zoning is visible in phosphorous (Fig. $3 \mathrm{~g}$ ).

\section{Integration of ground observations, satellite imagery and petrology}

Ground observations and satellite imagery

In a location as remote as Erta Ale, eruptions can occur unnoticed and unrecorded. The November 2010 eruption was short lived, which is typical of recent eruptions in Afar (e.g. Ferguson et al. 2010; Wright et al. 2006), and ordinarily, the brevity would not allow scientists sufficient time to travel to the eruption site to make observations. However, from the interpretation of the SEVERI features of the radiance time series, together with serendipitous ground observations, we can make inferences about the eruption chronology.
The SEVIRI data suggest the first thermal anomaly period occurred between 11 November and 14 November (Fig. 4), and records overflows onto the southern pit floor only. By the end of the first period, the pit floor had been covered with fresh lava flows, but the lake level was still low enough that the rim of the pit obscured it from view by SEVIRI. Ground observations from 11 November confirm that the southern pit was still $>20 \mathrm{~m}$ deep, comparable to its state 6 months earlier in February 2010 (Fig. 2a, b). However, by 14 November, the base of the pit was covered in fresh lava (J. Wilkinson, personal communication, December 2010). There then followed a hiatus of overflows, up until the start of the second thermal anomaly period, as seen by the lack of excess radiation (Fig. 4).

It was during this period of quiescence that seismic activity occurred in the Gulf of Aden [14-17 NovemberEuropean-Mediterranean Seismological Centre (EMSC 2010)] and around the town of Chiro (formerly Asebe Terferi) at the northern end of the Main Ethiopian Rift. Disturbance was also reported in the Danakil region with the opening of large sinkholes and unusually high groundwater levels. 
Table 5 Calculated

thermometry

\begin{tabular}{|c|c|c|c|c|c|c|c|}
\hline \multirow[t]{4}{*}{$\begin{array}{l}\text { Table } 5 \text { Calculated } \\
\text { thermometry }\end{array}$} & \multicolumn{5}{|c|}{ Matrix glass thermometry } & \multirow{2}{*}{\multicolumn{2}{|c|}{$\begin{array}{l}\text { Melt inclusion } \\
\text { thermometry }\end{array}$}} \\
\hline & \multirow{3}{*}{$\begin{array}{l}\text { Mineral } \\
\text { Method } \\
\text { Calibration error }\end{array}$} & \multirow{3}{*}{$\begin{array}{l}\begin{array}{l}\text { Plagioclase/liquid } \\
\text { (rim/glass) }\end{array} \\
\text { Putirka (2008) } \\
\pm 36^{\circ} \mathrm{C}\end{array}$} & \multirow{3}{*}{$\begin{array}{l}\begin{array}{l}\text { CPX/liquid } \\
\text { (rim/glass) }\end{array} \\
\text { Putirka } \\
(1996) \\
\pm 52{ }^{\circ} \mathrm{C}\end{array}$} & \multicolumn{2}{|c|}{$\begin{array}{l}\text { Olivine/liquid } \\
\text { (rim/glass) }\end{array}$} & & \\
\hline & & & & $\begin{array}{l}\text { Putirka } \\
(2008)\end{array}$ & $\begin{array}{l}\text { Beattie } \\
\text { (1993) }\end{array}$ & $\begin{array}{l}\text { Putirka } \\
(2007)\end{array}$ & Beattie (1993) \\
\hline & & & & $\pm 45^{\circ} \mathrm{C}$ & $\pm 44{ }^{\circ} \mathrm{C}$ & $\pm 45^{\circ} \mathrm{C}$ & $\pm 44^{\circ} \mathrm{C}$ \\
\hline & Temperature, ${ }^{\circ} \mathrm{C}$ & 1,176 & 1,165 & 1,158 & 1,157 & 1,126 & 1,132 \\
\hline & & 1,180 & 1,169 & 1,157 & 1,157 & 1,148 & 1,148 \\
\hline & & 1,176 & 1,151 & 1,158 & 1,157 & 1,094 & 1,104 \\
\hline & & 1,173 & 1,148 & 1,157 & 1,157 & 1,140 & 1,143 \\
\hline & & 1,180 & 1,167 & 1,157 & 1,157 & 1,121 & 1,129 \\
\hline & & 1,171 & 1,175 & 1,157 & 1,157 & & \\
\hline & & 1,178 & 1,169 & 1,152 & 1,157 & & \\
\hline & & & 1,167 & 1,151 & 1,157 & & \\
\hline & & & 1,157 & 1,155 & 1,157 & & \\
\hline & & & 1,170 & 1,157 & 1,157 & & \\
\hline & & & 1,170 & 1,155 & 1,157 & & \\
\hline & & & 1,162 & 1,155 & 1,157 & & \\
\hline & & & & 1,153 & 1,157 & & \\
\hline & & & & 1,153 & 1,157 & & \\
\hline & & & & 1,156 & 1,157 & & \\
\hline & & & & 1,157 & 1,157 & & \\
\hline & & & & 1,155 & 1,157 & & \\
\hline & & & & 1,155 & 1,157 & & \\
\hline All temperatures calculated from & Mean & 1,176 & 1,164 & 1,155 & 1,157 & 1,126 & 1,131 \\
\hline
\end{tabular}

All temperatures calculated from sample EA003
The field team arrived at $\sim 1600$ hours UTC on 21 November when the second phase of the eruption was well underway, and the southern pit had filled. SEVERI imaging suggests this second phase of activity began during 19 November, which indicates a rapid infilling of the southern pit between the 19th and 21st (Figs. 2 and 4). Assuming little or no activity between 15 and 19 November, a flow rate of approximately $2 \mathrm{~m}^{3} \mathrm{~s}^{-1}$ would be required to fill the area of the pit between 19 and 21 November (53 h). Oppenheimer and Francis (1997) estimated an average magma discharge rate (MDR) of $\sim 400 \mathrm{~kg} \mathrm{~s}^{-1}$ for February 1972-March 1973. Assuming the same density for comparison $(2,700 \mathrm{~kg}$ $\mathrm{m}^{-3}$ ), the calculated MDR for 19-21 November is $\sim 5,600 \mathrm{kgs}^{-1}$. The first overspill outside of the southern pit onto the main crater floor occurred at $\sim 1750$ hours UTC (Fig. 3a). Throughout the eruption, the lake was surrounded by a scoria ring cone which continued to build, similar to that observed in 1973 (Tazieff. 1973). Overspills continued at approximately 2-h intervals until $\sim 1430$ hours UTC on 22 November (Supplementary Video 1).

For the remainder of the ground observations, the lake was contained within the scoria ring, which had grown to
4 $\mathrm{m}$ high by 0300 hours UTC on 23 November. A 20-min cycle followed, with lava lake levels rising and falling by $>4 \mathrm{~m}$, during which, peak levels were marked by Strombolian activity. The northern part of the ring suffered a partial collapse on the morning of 23 November, which corresponds to a sharp peak at 0400 hours UTC in the SEVERI imaging (Fig. 4). Periodically, incandescent blue-green gas jets were observed similar in description to gas flames reported in January 2003, assumed to be $\mathrm{SO}_{2}$ (Vetsch et al. 2003). The northern pit also showed signs of activity with fresh lava flows erupted during the night of 21 November.

After the field team departed on 23 November, the eruption continued, with new overflows covering over the sampled flows, and nearly reaching the western rim of the caldera (Fig. 1; J. Hammond and J. Wilkinson, personal communication). The spacing between successive overflows became long enough that periods of sustained radiance can be identified, indicating that the lava lake had gained sufficient height to come into view of the sensor. SEVERI indicates lake activity persisted with sparse superimposed overflows for 7 days, followed by a period of sustained lake 
activity with no overflows for 6 days, and within a further 4 days, after 30 November, the lake signal disappeared, indicating a drop in lake level and occultation of the lake by the rim once again. Cloud cover prevents us determining the exact end of the eruption, but activity was confirmed to have ceased prior to 15 December (J. Wilkinson, personal communication, December 2010). In summary, the pattern appears to be (1) first period of lake level rise, (2) hiatus/drop in lake level, (3) lake level rise including lava overspills into the southern pit, (4) lake level stabilisation at high stand including lava overspills into the main crater and (5) lake level drop. The estimated total volume of both the erupted surface lava flows and the volume of lava required to fill the pit from the previous level is $\sim 0.006 \mathrm{~km}^{3}$, based on an estimated pit depth of $20 \mathrm{~m}$.

\section{Thermometry}

There is good agreement between temperatures determined in February 2001 by Burgi et al. (2002) using thermocouples and pyrometers $\left(1,145-1,187^{\circ} \mathrm{C}\right)$, and the petrological estimates reported here $\left(1,094-1,180^{\circ} \mathrm{C}\right)$. The temperatures are within error indicating a temperature for the system of $\sim 1,150{ }^{\circ} \mathrm{C}$, although there are likely to be some fluctuations within the conduit caused by magma circulation between magma storage, the conduit and the lake itself (Harris et al. 2005). Temperatures determined by Le Guern et al. (1979) in December 1971, January 1973 and 1974 provided a range of $1,100{ }^{\circ} \mathrm{C}$ through $1,210{ }^{\circ} \mathrm{C}$. The Le Guern field team directly inserted thermocouples into active hornitos, which may account for the differences between their study and the study of Burgi et al. (2002).
Volatiles

The petrology indicates that crystallisation is taking place in the upper $\sim 1.5 \mathrm{~km}$ of the conduit. The highest $\mathrm{H}_{2} \mathrm{O}$ content measured in the melt inclusions is low, $>0.13 \mathrm{wt} . \%$, lower than the water content proposed for a typical alkali basalt ( 0.5 wt.\%; e.g. Lowenstern and Mahood 1991). The low water values in the melt inclusions are very similar to basaltic melt inclusions from Hawaii (Fig.5a, Hauri 2002), but significantly lower than MORB (e.g. Pineau and Javoy 1994), Piton de la Fournaise, Réunion (Bureau et al. 1998) and Iceland (Nichols et al. 2002; Nichols and Wysoczanski 2007), which yield $\mathrm{H}_{2} \mathrm{O}$ contents up to 0.9 wt.\%. Low $\mathrm{H}_{2} \mathrm{O}$ and $\mathrm{CO}_{2}$ content can result from leakage, e.g. through cracks, and diffusive loss can occur through the host olivine. However, no cracks or bubbles were present in any of the inclusions studied. The positive correlations between trace elements and volatiles (Fig. 6) could not be preserved if significant $\mathrm{H}_{2} \mathrm{O}$ had diffused out of the inclusions as $\mathrm{H}_{2} \mathrm{O}$, $\mathrm{CO}_{2}$ and trace elements have very different diffusivities through olivine. The sole exception is melt inclusion $\mathrm{L}$ which has a slightly higher $\mathrm{Ba}$ than other melt inclusions (Fig. 6) and may represent entrapment of a slightly different melt composition. The overall trajectory of melt inclusion volatiles, namely, the large range in $\mathrm{CO}_{2}$ with little range in $\mathrm{H}_{2} \mathrm{O}$ (Fig. 5a), suggests that, although the magma became extensively degassed during ascent, the original magmatic $\mathrm{H}_{2} \mathrm{O}$ content was not significantly higher than $0.15 \mathrm{wt} . \%$.

There are several lines of evidence that the Erta Ale magma was volatile-saturated prior to eruption. Our $\mathrm{CO}_{2}-\mathrm{H}_{2} \mathrm{O}$ data define an array which is oblique to the isobars, consistent with decompression-driven degassing (Fig. 5a, b). However, the

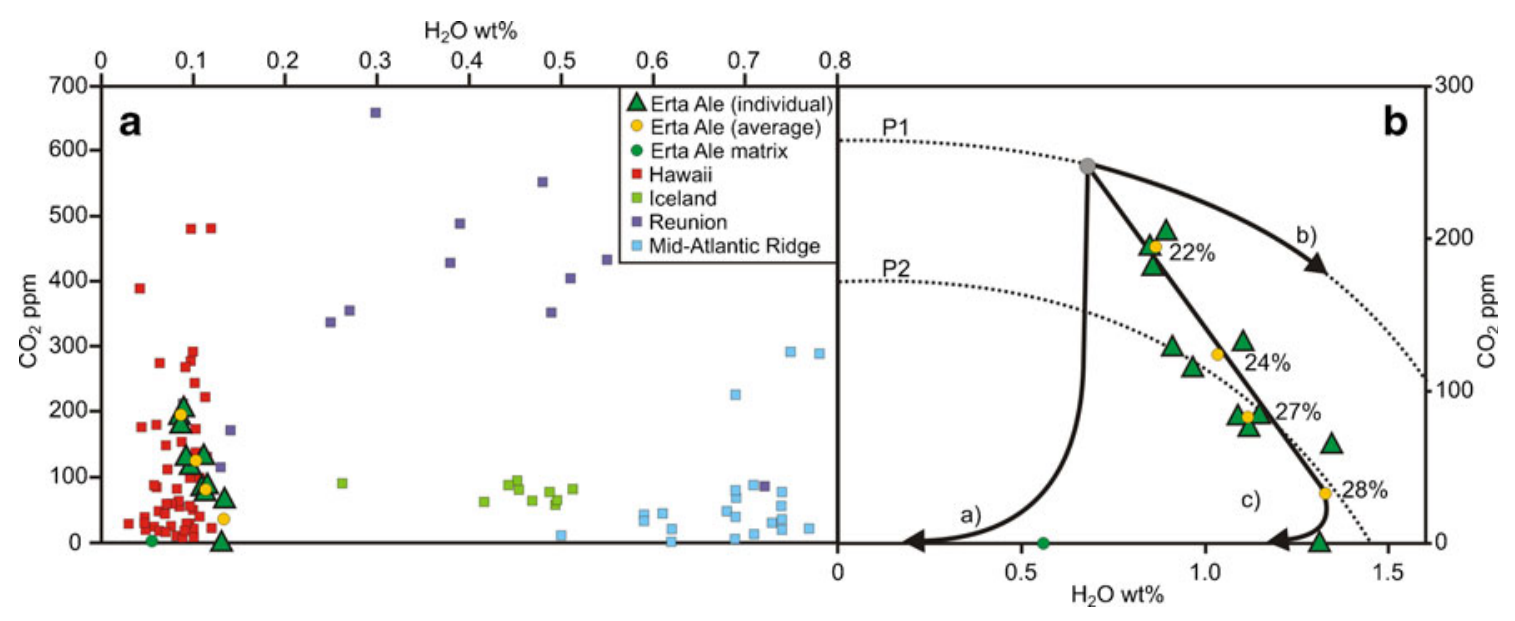

Fig. 5 a Plot of $\mathrm{CO}_{2}$ vs. $\mathrm{H}_{2} \mathrm{O}$ in melt inclusion and matrix glasses compared to other basaltic systems. Note broad agreement between Erta Ale (green triangles and yellow circles) and Hawaii (Hauri 2002). b Close-up of the data from Erta Ale (same symbols as a) indicating possible volatile evolution paths in melt inclusions (solid lines), based on Blundy and Cashman (2008). Dotted lines indicate schematic isobars for pressure $\mathrm{P} 1>\mathrm{P} 2$ (their exact positions are poorly constrained at these low pressures). Path $a$ indicates vapour-saturated decompression without crystallisation, path $b$ indicates isobaric vapour-saturated crystallisation and path $c$ indicates vapour-saturated decompression crystallisation. Percentages in $c$ indicate crystallisation. Path $c$ best describes the Erta Ale data. Values indicate approximate percentage of crystallisation calculated from the $\mathrm{Ba}$ values of averaged MI, normalised to whole-rock $\mathrm{Ba}$ 

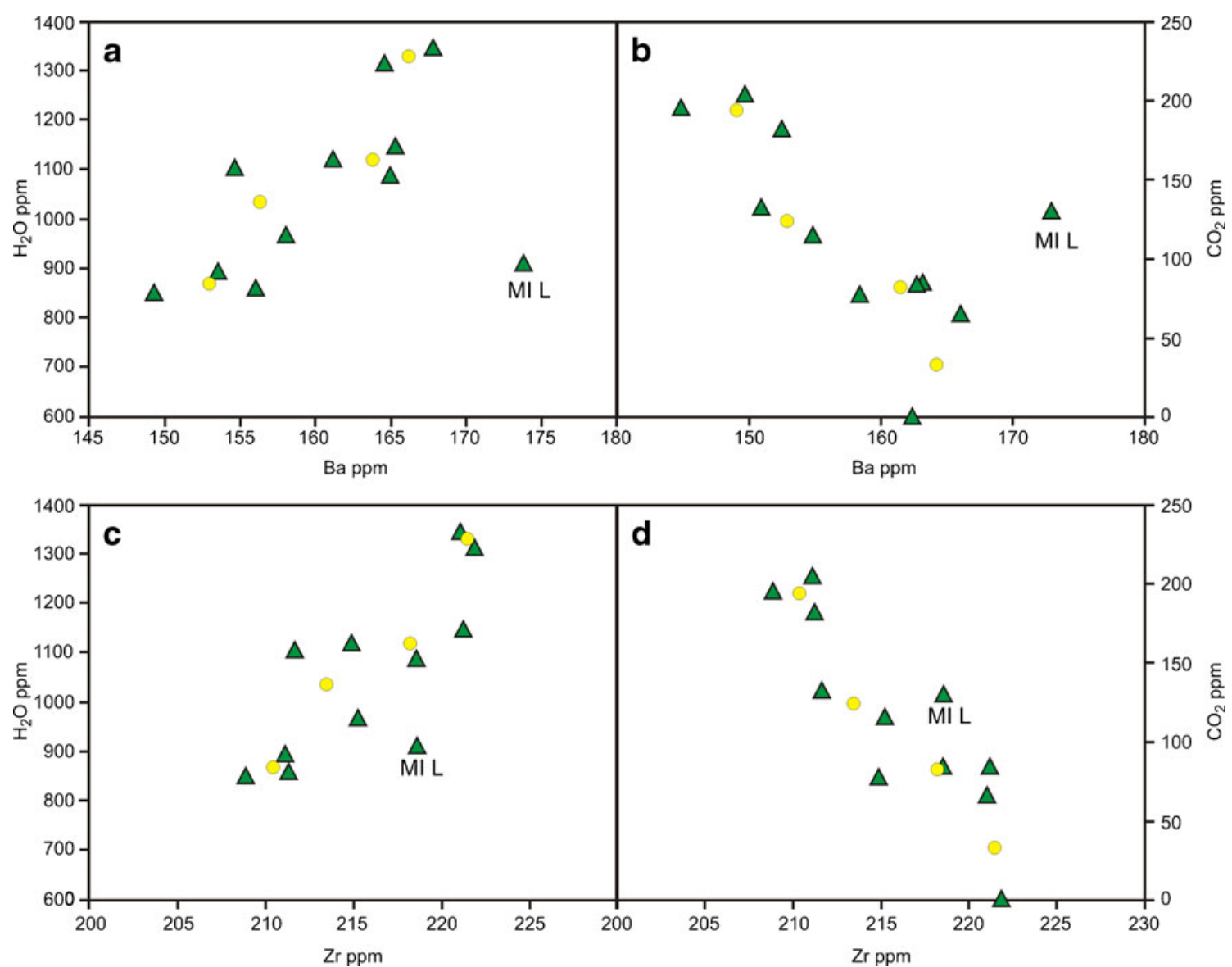

Fig. 6 Melt inclusion analyses of $\mathrm{H}_{2} \mathrm{O}(\mathbf{a}, \mathbf{c})$ and $\mathrm{CO}_{2}(\mathbf{b}, \mathbf{d})$ plotted against concentrations of the incompatible elements $\mathrm{Ba}$ and $\mathrm{Zr}$. These plots suggest that the November 2010 lavas experienced vapoursaturated crystallisation, as both $\mathrm{Ba}$ and $\mathrm{Zr}$ are positively correlated with $\mathrm{H}_{2} \mathrm{O}$ and negatively correlated with $\mathrm{CO}_{2}$. Green triangles show

negative slope of the array cannot be ascribed to degassing alone, which would produce a steep positive (sub-vertical) array, due to the much lower solubility of $\mathrm{CO}_{2}$ compared to $\mathrm{H}_{2} \mathrm{O}$. The positive correlation of an incompatible element, such as $\mathrm{Ba}$ or $\mathrm{Zr}$, with $\mathrm{H}_{2} \mathrm{O}$ (Fig. 6), and negative correlation with $\mathrm{CO}_{2}$ are consistent with vapour-saturated crystallisation (Blundy and Cashman 2008). A possible explanation is that crystallisation occurred concomitantly with decompression in Erta Ale magmas. Simple mass balance calculations for EA003 indicate $~ 19 \mathrm{vol} \%$ crystallisation is required to obtain the melt inclusion composition from the bulk rock, which is comparable to the modal volume for this sample of $\sim 18 \mathrm{vol} \%$, obtained by point counting. Note that if the inclusions had lost water by diffusion, the $\mathrm{H}_{2} \mathrm{O}$ (which diffuses more rapidly than $\mathrm{CO}_{2}$ ) would be displaced to low values at a given $\mathrm{CO}_{2}$ content, which is not observed (Fig. 5a).

The conclusion that Erta Ale magmas were volatilesaturated at shallow levels allows us to estimate, using VolatileCalc (Newman and Lowenstern 2002), the composition of the coexisting exsolved gas for comparison to previous individual SIMS analyses; yellow circles indicate the averaged analysis for each melt inclusion studied. Melt inclusion $(M I) \mathrm{L}$ lies distinct from the main melt inclusion trend and may represent the presence of a slightly different magma composition within the system

measurements from Erta Ale. The estimate for exsolved gas in November 2010 is $0.2-2.9 \mathrm{~mol}_{0} \mathrm{H}_{2} \mathrm{O}$ and $97.1-$ $99.8 \mathrm{~mol} \% \mathrm{CO}_{2}$, i.e. molar $\mathrm{H}_{2} \mathrm{O} / \mathrm{CO}_{2}$ ratios of 0.002 to 0.03 . There is appreciable uncertainty in this estimate due to the paucity of experimental data on basalts at low pressures. Nonetheless, these estimated volatile compositions are significantly more $\mathrm{H}_{2} \mathrm{O}$ poor than those determined by Gerlach (1980) and Sawyer et al. (2008) during passive degassing of the Erta Ale lava lake, who give molar $\mathrm{H}_{2} \mathrm{O}$ / $\mathrm{CO}_{2}$ ratios of 4-7 and 25, respectively (Table 6). As $\mathrm{CO}_{2}$ is considerably less soluble in basalt than $\mathrm{H}_{2} \mathrm{O}$, the elevated $\mathrm{H}_{2} \mathrm{O} / \mathrm{CO}_{2}$ suggests that passive degassing involves volatiles released at shallower depths than those at which melt inclusions were trapped. One way to evaluate this hypothesis is to calculate the composition of the total gas released by the ascending magma from the difference between melt inclusion and matrix glass volatile contents. This is, in effect, an integration of the gas released from the magma as it ascends to the surface. As the matrix glass has $\mathrm{CO}_{2}$ contents below detection, we assume all $\mathrm{CO}_{2}$ has been lost by degassing making our 
Table 6 Calculated molar gas ratios

\begin{tabular}{|c|c|c|c|c|c|c|c|c|c|c|}
\hline & \multicolumn{4}{|l|}{ This study } & \multicolumn{2}{|c|}{ Sawyer et al. (2008) } & \multicolumn{4}{|c|}{ Gerlach (1980) } \\
\hline & Average $^{a}$ & $\mathrm{sd}$ & $\mathrm{EA} 003 \mathrm{~J}^{\mathrm{b}}$ & sd & 2005 & sd & $1974^{\mathrm{c}}$ & $1973^{d}$ & $1973^{\mathrm{d}}$ & $1971^{\mathrm{e}}$ \\
\hline $\mathrm{H}_{2} \mathrm{O} / \mathrm{CO}_{2}(\mathrm{~mol})$ & 10.7 & 7.2 & 9.4 & 1.6 & 24.8 & 0.8 & 6.6 & 3.8 & 3.7 & 3.9 \\
\hline $\mathrm{CO}_{2} / \mathrm{SO}_{2}$ & 0.7 & 0.5 & 0.5 & 0.1 & 1.5 & 0.1 & 1.6 & 2.7 & 4 & 2 \\
\hline $\mathrm{SO}_{2} / \mathrm{Cl}$ & 1.9 & 3.1 & 1.0 & 0.6 & 12.4 & 0.2 & 18.6 & & & \\
\hline $\mathrm{H}_{2} \mathrm{O} / \mathrm{SO}_{2}$ & 7.1 & 3.8 & 5.0 & 0.8 & 38 & 3 & 10.4 & 10.4 & 14.5 & 7.9 \\
\hline
\end{tabular}

${ }^{a}$ Average from this study, calculated using melt inclusion minus matrix analysis for each species

${ }^{b}$ Example of an individual melt inclusion, calculated using melt inclusion minus matrix analysis for each species

${ }^{\mathrm{c}}$ Ratios from restored gas analysis (Gerlach 1980) (gases originally collected in 1974 from hornitos by Giggenbach and Le Guern)

${ }^{\mathrm{d}}$ Ratios from restored gas analysis (Gerlach 1980) (1973 gases originally collected from a hornito by Le Guern)

${ }^{\mathrm{e}}$ Ratios from restored gas analysis (Gerlach 1980) (1971 samples originally collected by Tazieff)

$\mathrm{H}_{2} \mathrm{O} / \mathrm{CO}_{2}$ estimates maxima. Our calculated values for molar $\mathrm{H}_{2} \mathrm{O} / \mathrm{CO}_{2}$ from individual melt inclusions lie in the range 457 with an average for the entire population of $11 \pm 7$. These $\mathrm{H}_{2} \mathrm{O} / \mathrm{CO}_{2}$ ratios fall within the range determined by Sawyer et al. (2008) and Gerlach (1980). This suggests that the composition of the gas released from the magma is consistent, quantitatively, with exsolution of pre-eruptive volatiles contained within the magma; if a significant population of bubbles of deeper, magmatic gas with elevated $\mathrm{CO}_{2} / \mathrm{H}_{2} \mathrm{O}$ was present in the magma prior to ascent, this would reduce the $\mathrm{H}_{2} \mathrm{O} / \mathrm{CO}_{2}$ ratio of the gas below the values observed by Sawyer et al. (2008) and Gerlach (1980).

The calculated molar $\mathrm{SO}_{2} / \mathrm{Cl}$ ratio of the released gas is in the range 1.0-2.0 (Table 6) compared to 12-19 measured in field studies (Gerlach 1980; Sawyer et al. 2008). As chlorine is the last volatile species to be exsolved from magma, the $\mathrm{SO}_{2} / \mathrm{Cl}$ ratio is a sensitive indicator of degassing depth (Lesne et al. 2011): higher ratios denote shallower degassing. Our low $\mathrm{SO}_{2} / \mathrm{Cl}$ ratios are consistent with complete degassing upon eruption in November 2010. Conversely, the lava lake gas measurement of Gerlach (1980) and Sawyer et al. (2008), which were made at a time when the lava was contained within the pit and not overflowing into the main crater, likely records a slightly deeper level of degassing, probably due to circulation within the conduit, giving rise to higher $\mathrm{SO}_{2} / \mathrm{Cl}$ ratios. These small changes in degassing depth will not have significant effect on the $\mathrm{H}_{2} \mathrm{O} / \mathrm{CO}_{2}$ ratios, as almost all $\mathrm{CO}_{2}$ is lost prior to the onset of $\mathrm{Cl}$ degassing (Lesne et al. 2011). A schematic illustration of the Erta Ale shallow plumbing system that is consistent with the observed differences in gas composition between eruptive and non-eruptive (passive) degassing episodes is shown in Fig. 7.

The difference in $\mathrm{SO}_{2}$ contents of melt inclusions and matrix glass is in the range 160 to $330 \mathrm{ppm}$ (Table 4).
Assuming that the November 2010 magma had a similar composition to that in the lava lake in 2005 when studied by Sawyer et al. (2008), we calculate the total magma flux through the conduit required to sustain their observed $\mathrm{SO}_{2}$ flux $\left(0.69 \pm 0.17 \mathrm{~kg} \mathrm{~s}^{-1}\right)$ to be in the range $2,090 \pm 520$ to $4,310 \pm 1,060 \mathrm{kgs}^{-1}$. A broadly similar magma flux, calculated in the same way, can sustain the range of $\mathrm{CO}_{2}$ fluxes measured by Sawyer et al. (2008). However, a higher flux, by a factor of two, is required to sustain the observed $\mathrm{H}_{2} \mathrm{O}$ flux. This mismatch may be rooted in the combined uncertainties on the analytical and gas measurement data, or reflect, as suggested above, small differences in the degassing depths between and during eruptions. Sawyer et al. (2008) noted that the $\mathrm{H}_{2} \mathrm{O}$ in the volcanic plume had significantly increased in the 30 years since Gerlach's (1980) work, and suggested this may be related to volatile depletion of the deep source magma and/or to fractional magma degassing. Alternatively, variation in the $\mathrm{H}_{2} \mathrm{O}$ content of Erta Ale gases may reflect systematic changes in the depth within the conduit at which gases are extracted. In any case, our calculations lend support to the idea that the observed gas flux can be provided by near-complete degassing of magma passing through the shallow conduit system at rates of $\sim 3,000-7,000 \mathrm{kgs}^{-1}$. It does not appear that any substantial additional source of gas, i.e. gas-fluxing, is required to account for the field measurements of gas flux at Erta Ale.

The Erta Ale lavas show a high vesicularity (up to $\sim 60 \%$ ), which may initially seem surprising given the low volatile contents indicated by the melt inclusions. Using the ideal gas law, the average value for lost $\mathrm{H}_{2} \mathrm{O}$ of $450 \mathrm{ppm}$ (i.e. melt inclusion minus groundmass), a temperature of $1,150{ }^{\circ} \mathrm{C}$, standard atmospheric pressure and an assumed density for basalt of 2,700 $\mathrm{kgm}^{-3}$ (e.g. Oppenheimer and Francis 1997), a gas volume of $2.92 \times 10^{-3} \mathrm{~m}^{3}$ is obtained, $\sim 8$ times more gas than melt. This indicates that if $10 \%$ degassing were to take 


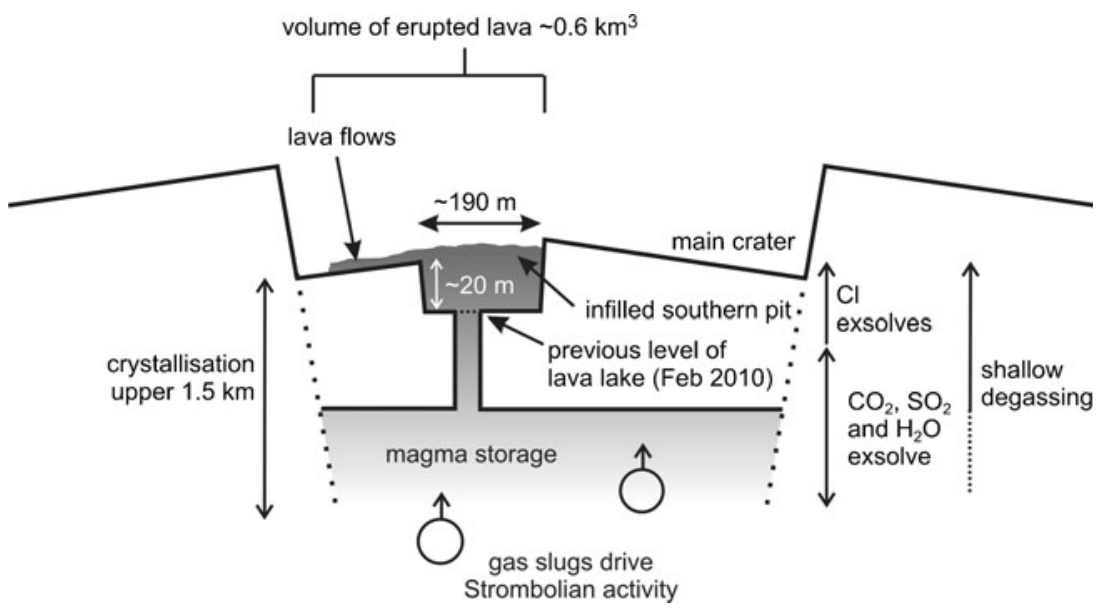

Fig. 7 Schematic of the Erta Ale shallow plumbing system in November 2010 based on integrated ground and satellite observations and petrology (not to scale). The arrows on the right hand side illustrate how gas extraction from different depths influences gas composition, with elevated $\mathrm{Cl}$ characteristic of very shallow degassing. Passive

place, $\sim 40 \%$ vesicularity would result, and $20 \%$ degassing would result in $\sim 60 \%$ vesicularity. Thus, releasing $<448 \mathrm{ppm}$ gas at, or close to, the surface at the eruption temperature is sufficient to generate the observed high vesicularities. Melt inclusion volatile data are also not suggestive of the presence of significant pre-eruptive bubbles in the magma during passive degassing episodes (see above). However, we cannot rule out the possibility that an influx of additional gas drove the Strombolian activity observed in 2010. We have no field measurements of this degassing episode with which to test our hypothesis, but it does seem likely that an additional gas source was required to sustain the observed eruptive vigour. degassing does not appear to require an additional source of gas to explain the measured gas chemistry; it is sufficient that magma ascends from the storage region to the lake itself releasing its volatiles en-route. However, it is possible that vigorous Strombolian activity is triggered by the ascent of large bubbles from depth as shown schematically

During eruption, the viscosity of the lava appeared to be very low (Supplementary Video 1). The calculated viscosity of the melt at eruption temperature using the model of Giordano et al. (2008) is 70 Pas. The small fraction of crystals ( $\sim 18 \mathrm{vol} \%$ in EA003) is unlikely to have had any major impact on the viscosity (Caricchi et al. 2007). However, the vesicularity would have had a greater effect. The vesicles observed in the Erta Ale samples are highly elongate, which would have resulted in a lowering of viscosity, whilst spherical vesicles would instead have acted like phenocrysts to raise the viscosity (Llewellin and Manga 2005). Consequently, the calculated viscosity of the vesicular magma is reduced to $5 \mathrm{Pas}(\mathrm{Pal}$ 2003) or 15 Pas (Llewellin and Manga 2005).

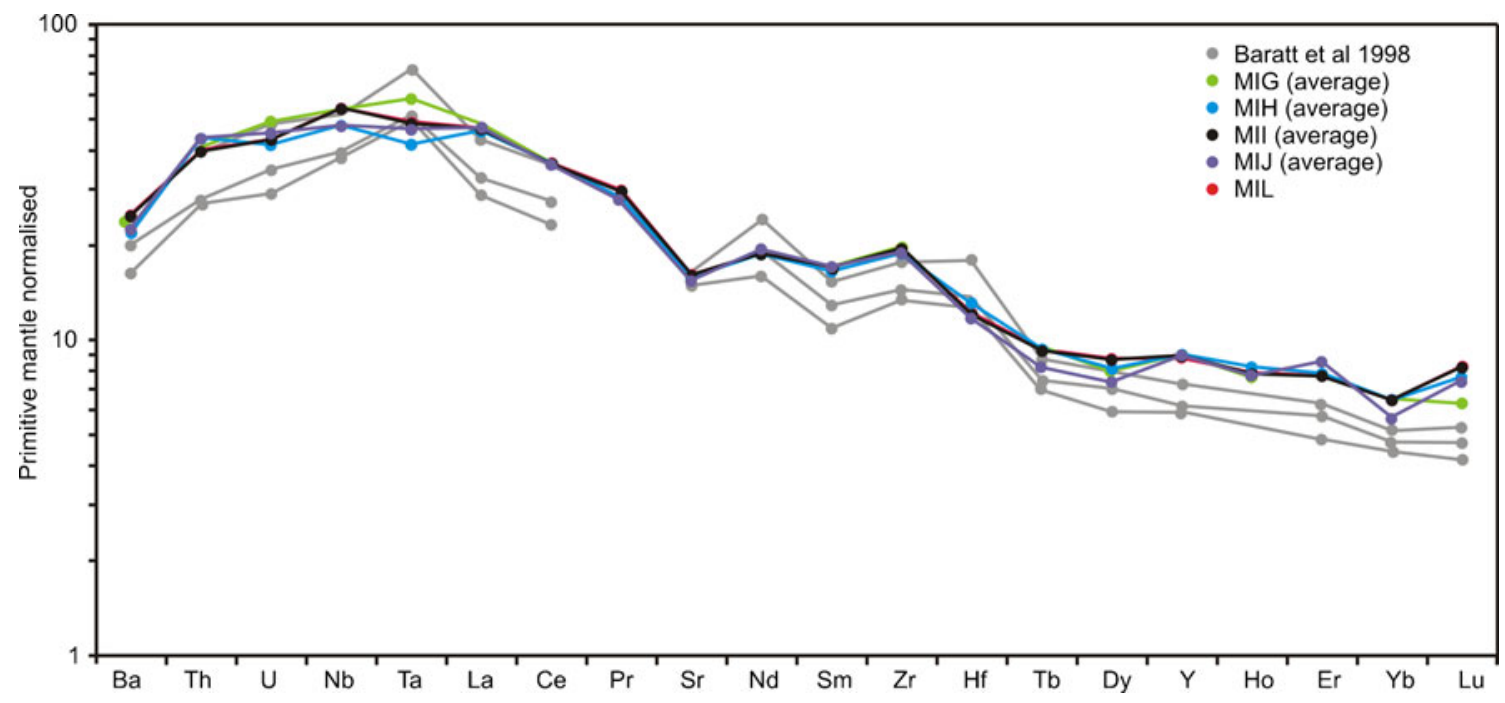

Fig. 8 Trace element compositions normalised to primitive mantle (Sun and McDonough 1989) of melt inclusions, with whole rock data from an Erta Ale basalt of Barrat et al. (1998) for comparison. The broadly similar patterns are consistent with crystallisation of an olivine-dominated phenocryst assemblage. The small negative $\mathrm{Sr}$ anomaly is consistent with plagioclase crystallisation 


\section{Geochemistry}

A key question is whether the geochemistry of the 2010 lavas is sufficiently different from those of earlier Erta Ale lavas to indicate that recharge of the magma system occurred subsequent to 1973 . We have already shown that the 1973 lavas appear to be texturally and chemically distinct from those of 2010. However, these differences can be readily reconciled with a slightly increased degree of fractionation of EA002, as evinced by higher contents of incompatible elements, and lower temperatures as suggested by their more crystalline, microlite-rich texture. Overall, however, the 1973 and 2010 lavas are sufficiently similar to each other and within the range of Erta Ale Range lavas that it seems unlikely that any recharge of the system since 1973 involved a truly distinct magma type. Nonetheless, the renewal of activity, the reduction in differentiation and crystallinity strongly suggest that the sub-volcanic reservoir was refilled by hotter, compositionally similar basaltic magma.

\section{Trace element systematics}

Trace elements concentrations normalised to primitive mantle (Sun and McDonough 1989) are plotted in Fig. 8. Whole rock samples from Barrat et al. (1998) are shown for comparison. The melt inclusions have a similar overall pattern to the whole rocks, but are displaced to the high concentration end of the whole-rock range, consistent with a modest amount of crystallisation $(\sim 20 \%)$ of trace element poor phenocrysts. The small negative anomaly for $\mathrm{Sr}$, in both melt inclusions and whole rocks, is consistent with crystallisation of plagioclase. The presence of plagioclase inclusions in both cpx and olivine crystals indicates plagioclase was already crystallising when melt inclusions were entrapped in olivine. Europium, which also partitions strongly into plagioclase, was not measured in the melt inclusions due to the large isobaric interference of $\mathrm{BaO}$ on $\mathrm{Eu}$ at the mass resolution used for trace element analyses.

The relationship between the whole rocks and the melt inclusions is further illustrated using log-log plots in Fig. 9. The melt inclusions define linear trends that extend away from the 2010 whole rocks along vectors consistent with $\sim 20 \%$ crystallisation of an olivine-dominated assemblage with plagioclase and cpx. The range in trace element contents of the suite of melt inclusions records continued crystallisation of the same assemblage. The correlations between incompatible elements and volatile species (Fig. 6) suggest that this crystallisation occurred concomitantly with degassing. The subtle geochemical differences between the 2010 lavas and those of the lava floor are suggestive of magma refill of slightly different composition, although there is insufficient data to fully evaluate this possibility.

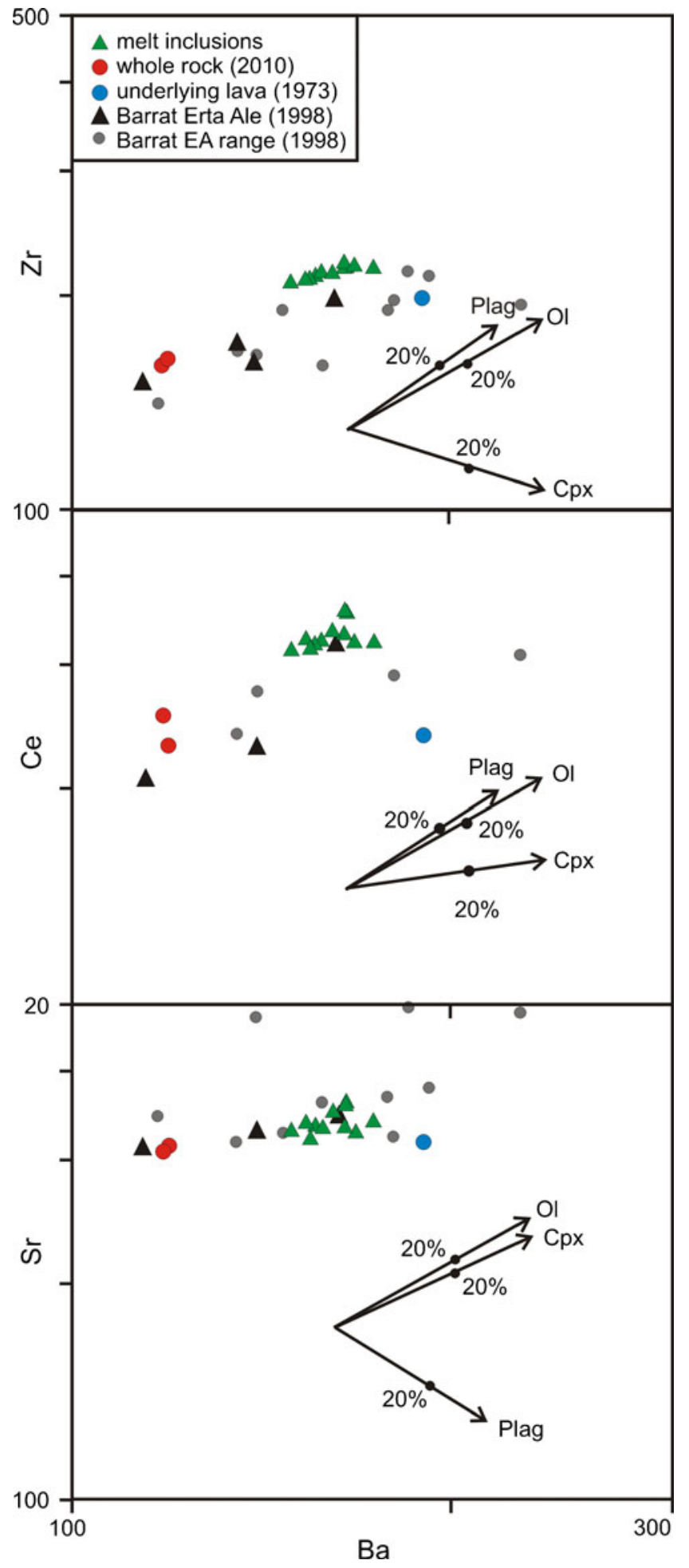

Fig. $9 \mathrm{Log}-\log$ trace element plots for individual melt inclusion analyses and whole rock. Vectors show the effect of fractionation of plagioclase, clinopyroxene and olivine using partition coefficients from Rollinson (1993). The filled circles denote 20 wt.\% fractionation. Data from Barrat et al. (1998) from both the Erta Ale volcano and the Erta Ale range has been included for comparison 
Magmatic timescales

$\mathrm{K} \alpha \mathrm{X}$-ray mapping revealed phosphorous zoning in the olivines, which was not apparent for other elements, e.g. Fe (Fig. 3h). Phosphorous diffuses extremely slowly compared to $\mathrm{Fe}-\mathrm{Mg}$ and $\mathrm{Ca}$ in olivine (Milman-Barris et al. 2008; Spandler and O'Neill 2010). Hence, the P zoning is preserved, whilst $\mathrm{Fe}-\mathrm{Mg}$ and $\mathrm{Ca}$ are homogenised during residence in hot magma. An estimate of the minimum time it would take to homogenise the crystal with respect to $\mathrm{Fe}-\mathrm{Mg}$ and $\mathrm{Ca}$ at magmatic temperatures can be obtained from the characteristic diffusion length $\left(x=(D t)^{1 / 2}\right.$; where $x=$ distance, $D=$ diffusivity, $t=$ time) of each element of interest. Diffusion coefficients for $\mathrm{Ca}$ and $\mathrm{Fe}-\mathrm{Mg}$, parallel to the $c$-axis, were calculated using the models of Coogan et al. (2005), Dohmen et al. (2007) and Dohmen and Chakraborty (2007) at a magmatic temperature of $1,170{ }^{\circ} \mathrm{C}$ and an oxygen fugacity equivalent to the QFM buffer. For a typical $200-\mu \mathrm{m}$ olivine crystal, $\mathrm{Fe}-\mathrm{Mg}$ would have homogenised in approximately 0.2 years, and $\mathrm{Ca}$ in 10 years, providing a minimum estimate for the residence time of a crystal within this magma. Phosphorous diffusion rates have not been constrained, but are at least two orders of magnitude slower than other major cations (Spandler and O'Neill 2010). Studies of experimental and natural olivines have shown $\mathrm{P}$ and $\mathrm{Cr}$ to be correlated (Milman-Barris et al. 2008). Cr diffusion coefficients (Ito and Ganguly 2006) were therefore used to give an indication of the minimum timescales required to eradicate the $\mathrm{P}$ zoning. This gives a minimum timescale of $\sim 94$ years for homogenisation of $\mathrm{P}$ within a typical $200-\mu \mathrm{m}$ olivine crystal, as modelled here. As $\mathrm{P}$ is not homogenous in the studied olivines, this timescale provides an upper limit for residence of this crystal. Although crystals can be retained in the subvolcanic system following an eruptive episode, it is considered that this is unlikely as the texture and appearance of crystals in the 2010 samples (EA001 and 3) are very different from the underlying lava (EA002) from the previous overspill (compare Fig. 3e, f). The last observed eruptive episode at Erta Ale was in 1973. The fact that the estimated timescales are of the order of decades, a period comparable to that elapsed since Erta Ale last erupted, is consistent with our earlier inferences that the magma system was recharged by a new pulse of hotter magma subsequent to 1973 (refer to Supplementary Table 5), we think these eruptive episodes are sufficiently infrequent that the period between the eruptions acts as an upper bound and therefore suggest that the crystal residence time was between $\sim 10$ and $\sim 37$ years.

\section{Conclusions}

We present an integrated field, satellite and petrological study of the November 2010 eruption of the Erta Ale volcano. The timeline of this small, but rare, eruption has been reconstructed from a combination of ground observations and SEVERI imaging. Two phases occurred, beginning on 11 and 19 November 2010. Pristine melt inclusions have shown the Erta Ale magma to be relatively dry $\left(<0.15\right.$ wt. $\left.\% \mathrm{H}_{2} \mathrm{O}\right)$, although several petrological lines of evidence suggest the magma was volatile-saturated prior to eruption. The low volatile contents within the melt inclusions are sufficient at eruption temperature and low pressure, to account for the vesicularity of the erupted lava. The eruption and overflow of magma from the lava lake in November 2010 facilitated almost complete magma degassing. The calculated composition of the released gas is broadly consistent with measured passive emissions of volcanic gas from the Erta Ale lava lake, although the higher measured $\mathrm{SO}_{2} / \mathrm{Cl}$ ratios suggests that degassing during non-eruptive episodes did not proceed to the same extent as it did during the 2010 eruption. Coupled trace and volatile element systematics indicate that crystallisation took place at shallow levels, in the top $\sim 1.5 \mathrm{~km}$ of the conduit, largely in response to degassing. We tentatively conclude that slightly hotter, but broadly similar, magma was injected into the magmatic system after 1973, and that typical phenocryst residence times indicated by phenocrysts in the 2010 samples were between $\sim 10$ and 37 years. The 2010 samples are shown to be quite distinct from the underlying lava from the previous overspills in 1973.

The November 2010 eruption was coincident with a seismic swarm in the Gulf of Aden; increased activity in 2005 was also noted to be coincident with the 2005 volcanoseismic crisis in the Manda-Hararo magmatic rift segment. It is possible that Erta Ale is particularly sensitive to tectonic activity in the region, but future monitoring will be required to confirm this.

Acknowledgments This research was funded by the Natural Environmental Research Council, Afar Rift Consortium grant NE/F007604/1. K.S. was supported by a NERC Post-doctoral Research Fellowship (NE/ G0129X/1). The authors acknowledge the generous support of the University of Addis Ababa with fieldwork arrangements, and the Afar Regional Government for invaluable assistance. We thank N. Marsh and R. Kelly for assistance with XRF at the University of Leicester, R. Hinton with the SIMS at the University of Edinburgh and J. Hammond for the GPS track of the final emplaced lava flow (February 2011). J. Wilkinson is thanked for sharing his observations during and posteruption. T. Rooney provided some helpful comments on an earlier version of the manuscript. The manuscript was also improved by the comments of two anonymous reviewers.

\section{References}

Ayele A, Jacques E, Kassim M, Kidane T, Omar A, Tait S, Nercessian A, de Chabalier J, King G (2007) The volcano-seismic crisis in Afar, Ethiopia starting September 2005. Earth Planet Sci Lett 255 $(1-2): 177-187$ 
Barrat JA, Fourcade S, Jahn BM, Cheminee JL, Capdevila R (1998) Isotope $(\mathrm{Sr}, \mathrm{Nd}, \mathrm{Pb}, \mathrm{O})$ and trace-element geochemistry of volcanics from the Erta Ale range (Ethiopia). J Volcanol Geotherm Res 80(1-2):85-100

Barberi F, Varet J (1970) The Erta Ale volcanic range (Danakil depression, northern Afar, Ethiopia). Bull Volcanol 34(4):848-917

Barberi F, Santacroce R, Varet J (1974) Silicic peralkaline volcanic rocks of the Afar depression (Ethiopia). Bull Volcanol 38(2):755-790

Barberi F, Varet J (1977) Volcanism of Afar-small-scale plate tectonic implications. Geol Soc Am Bull 88(9):1251-1266

Bardintzeff J, Gaudru H (2004) 11/2004 (BGVN 29:11) Bulletin of the Global Volcanism Network. Smithsonian Institute, Global Volcanism Program. www.si.edu. Accessed Jan 2011

Beattie P (1993) Olivine-melt and orthopyroxene-melt equilibria. Contrib Mineral Petrol 115(1):103-111

Bizouard H, Barberi F, Varet J (1980) Mineralogy and petrology of Erta Ale and Boina volcanic series, Afar Rift, Ethiopia. J Petrol 21 (2):401-436

Blundy J, Cashman K (2008) Petrologic reconstruction of magmatic system variables and processes. In: Putirka KD, Tepley FJ (eds) Minerals, inclusions and volcanic processes. Mineralogical Society of America, Chantilly, pp 179-239

Bureau H, Pineau F, Métrich N, Semet MP, Javoy M (1998) A melt and fluid inclusion study of the gas phase at Piton de la Fournaise volcano (Réunion Island). Chem Geol 147(1-2):115-130

Burgi P-Y, Caillet M, Haefeli S (2002) Field temperature measurements at Erta'Ale Lava Lake, Ethiopia. Bull Volcanol 64(7):472-485

Caricchi L, Burlini L, Ulmer P, Gerya T, Vassalli M, Papale P (2007) Non-Newtonian rheology of crystal-bearing magmas and implications for magma ascent dynamics. Earth Planet Sci Lett 264(34):402-419

Coogan LA, Hain A, Stahl S, Chakraborty S (2005) Experimental determination of the diffusion coefficient for calcium in olivine between $900^{\circ} \mathrm{C}$ and $1500^{\circ} \mathrm{C}$. Geochim Cosmochim Acta 69 (14):3683-3694

Dainelli G, Marinelli O (1907) Vulcani attivi della Dancalia. Riv Geog Ital 13:261-270

Davies AG, Keszthelyi LP, Harris AJL (2010) The thermal signature of volcanic eruptions on Io and Earth. J Volcanol Geotherm Res 194 (4):75-99

Dixon JE, Stolper E, Delaney JR (1988) Infrared spectroscopic measurements of $\mathrm{CO}_{2}$ and $\mathrm{H}_{2} \mathrm{O}$ glasses in the Juan de Fuca Ridge basaltic glasses. Earth Planet Sci Lett 90:87-104

Dohmen R, Becker HW, Chakraborty S (2007) Fe-Mg diffusion in olivine I: experimental determination between 700 and 1,200 degrees $\mathrm{C}$ as a function of composition, crystal orientation and oxygen fugacity. Phys Chem Miner 34(6):389-407

Dohmen R, Chakraborty S (2007) Fe-Mg diffusion in olivine II: point defect chemistry, change of diffusion mechanisms and a model for calculation of diffusion coefficients in natural olivine. Phys Chem Miner 34(6):409-430

EMSC - European-Mediterranean Seismological Centre (2010) EMSC website: http://www.emsc-csem.org. Accessed 01 Dec 2010

Ferguson DJ, Barnie TD, Pyle DM, Oppenheimer C, Yirgu G, Lewi E, Kidane T, Carn S, Hamling I (2010) Recent rift-related volcanism in Afar, Ethiopia. Earth Planet Sci Lett 292(3-4):409-418

Fine G, Stolper E (1986) Dissolved carbon dioxide in basaltic glasses: concentrations and speciation. Earth Planet Sci Lett 76:263-278

Gerlach TM (1980) Investigation of volcanic gas analyses and magma outgassing from Erta 'Ale lava lake, Afar, Ethiopia. J Volcanol Geotherm Res 7(3-4):415-441

Giordano D, Russell JK, Dingwell D (2008) Viscosity of magmatic liquids: a model. Earth Planet Sci Lett 271:123-134

Harris AJL, Carniel R, Jones J (2005) Identification of variable convective regimes at Erta Ale Lava Lake. J Volcanol Geotherm Res 142(3-4):207-223
Hauri E (2002) SIMS analysis of volatiles in silicate glasses, 2: isotopes and abundances in Hawaiian melt inclusions. Chem Geol 183(1-4):115-141

Hirn B, Di Bartola C, Ferrucci F (2009) Combined use of SEVIRI and MODIS for detecting, measuring, and monitoring active lava flows at erupting volcanoes. IEEE Trans Geosci Remote Sens 47(2):2923-2930

Irvine TN, Baragar WRA (1971) A guide to the chemical classification of the common volcanic rocks. Can J Earth Sci 8:523-548

Ito M, Ganguly J (2006) Diffusion kinetics of $\mathrm{Cr}$ in olivine and 53Mn$53 \mathrm{Cr}$ thermochronology of early solar system objects. Geochim Cosmochim Acta 70(3):799-809

Le Guern F, Carbonnelle J, Tazieff H (1979) Erta 'Ale lava lake: heat and gas transfer to the atmosphere. J Volcanol Geotherm Res 6(12):27-48

Lesne P, Kohn S, Blundy J, Witham F, Botcharnikov R, Behrens H (2011) Experimental simulation of closed-system degassing in the system basalt- $\mathrm{H}_{2} \mathrm{O}-\mathrm{CO}_{2}$-S-Cl. J Petrol 52:1737-1762

Llewellin EW, Manga M (2005) Bubble suspension rheology and implications for conduit flow. J Volcanol Geotherm Res 143(13):205-217

Lowenstern JB, Mahood GA (1991) New data on magmatic $\mathrm{H}_{2} \mathrm{O}$ contents of pantellerites with implications for petrogenesis and eruptive dynamics at Pantelleria. Bull Volcanol 54(1):78-83

Mahatsente R, Jentzsch G, Jahr T (1999) Crustal structure of the Main Ethiopian Rift from gravity data: 3-dimensional modeling. Tectonophysics 313(4):363-382

Milman-Barris MS, Beckett JR, Baker MB, Hofmann AE, Morgan Z, Crowley MR, Vielzeuf D, Stolper E (2008) Zoning of phosphorus in igneous olivine. Contrib Mineral Petrol 155(6):739-765

Müller J (2010) MSG Level 1.5 Image data format description. Eumetsat documentation online EUM/MSG/ICD/105. http:// www.eumetsat.int/groups/ops/documents/document/pdf_ten $05105 \mathrm{msg}$ img data.pdfV6. Accessed 23 Feb 2010

Nesbitt LM (1935) Hell-hole of creation: the exploration of Abyssinian Danakil. Alfred. A. Knopf, New York, p 382

Newman S, Lowenstern JB (2002) VolatileCalc: a silicate melt- $\mathrm{H}_{2} \mathrm{O}$ $\mathrm{CO}_{2}$ solution model written in Visual Basic for Excel. Comput Geosci 28(5):597-604

Nichols ARL, Carroll MR, Hoskuldsson A (2002) Is the Iceland hot spot also wet? Evidence from the water contents of undegassed submarine and subglacial pillow basalts. Earth Planet Sci Lett 202 (1):77-87

Nichols ARL, Wysoczanski RJ (2007) Using micro-FTIR spectroscopy to measure volatile contents in small and unexposed inclusions hosted in olivine crystals. Chem Geol 242:371-384

Oppenheimer C, Francis P (1997) Remote sensing of heat, lava and fumarole emissions from Erta Ale volcano, Ethiopia. Int J Remote Sens 18(8):1661-1692

Pal R (2003) Rheological behaviour of bubble-bearing magmas. Earth Planet Sci Lett 207:165-179

Pagli C, Wright TJ, Ebinger CJ, Yun S, Cann JR, Barnie T, Ayele A (2012) Shallow axial magma chamber at the slow-spreading Erta Ale Ridge. Nat Geosci 5284-5288. doi:10.1038/ngeo1414

Pineau F, Javoy M (1994) Strong degassing at ridge crests: the behaviour of dissolved carbon and water in basalt glasses at $14^{\circ} \mathrm{N}$, MidAtlantic Ridge. Earth Planet Sci Lett 123(1-3):179-198

Prodehl C, Fuchs K, Mechie J (1997) Seismic-refraction studies of the Afro-Arabian rift system - a brief review. Tectonophysics 278(14):1-13

Putirka K, Johnson M, Kinzler R, Longhi J, Walker D (1996) Thermobarometry of mafic igneous rocks based on clinopyroxene-liquid equilibria, 0-30 kbar. Contrib Mineral Petrol 123(1):92-108

Putirka KD (2008) Thermometers and barometers for volcanic systems. Minerals, inclusions and volcanic processes. Rev Min Geochem 69:61-120 
Rollinson H (1993) Using geochemical data: evaluation, presentation, interpretation. Longman Scientific, New York

Sawyer GM, Oppenheimer C, Tsanev VI, Yirgu G (2008) Magmatic degassing at Erta 'Ale volcano, Ethiopia. J Volcanol Geotherm Res 178(4):837-846

Shishkina TA, Botcharnikov RE, Holtz F, Almeev RR, Portnyagin MV (2010) Solubility of $\mathrm{H}_{2} \mathrm{O}$ and $\mathrm{CO}_{2}$ bearing fluids in tholeiitic basalts at pressures up to $500 \mathrm{MPa}$. Chem Geol 277(1-2):115-125

Spandler C, O'Neill H (2010) Diffusion and partition coefficients of minor and trace elements in San Carlos olivine at $1,300^{\circ} \mathrm{C}$ with some geochemical implications. Contrib Mineral Petrol 159 (6):791-818

Sun S, McDonough WF (1989) Chemical and isotopic systematics of oceanic basalts: implications for mantle composition and processes. In: Saunders AD, Norry MJ (eds) Magmatism in the ocean basins. Geol Soc Sp 42:313-345

Tazieff H (1973) Erta Ale volcano. Rev Geol Dyn Geogr 15(4):437-441

Varet J (1972) 03/1972 (CSLP 16-72) Card 1363 (06 March 1972). Bulletin of the Global Volcanism Network. Smithsonian Institute, Global Volcanism Program. www.si.edu. Accessed January 2011

Varet J (1972) 05/1972 (CSLP 16-72) Card 1390 (10 May 1972). Bulletin of the Global Volcanism Network. Smithsonian Institute, Global Volcanism Program. www.si.edu. Accessed January 2011
Vetsch P, Assefa G, Asfaw L (1992) 09/1992 (BGVN 17:09) Bulletin of the Global Volcanism Network. Smithsonian Institute, Global Volcanism Program. www.si.edu. Accessed January 2011

Vetsch P, Caillet M, Haefeli S, Burgi P-Y (2003) 04/2003 (BGVN 28:04) Bulletin of the Global Volcanism Network. Smithsonian Institute, Global Volcanism Program. www.si.edu. Accessed January 2011

Wilson SA (1997) The collection, preparation and testing of USGS reference material BCR-2, Columbia river, basalt. USGS OpenFile Report 98-xxx

Wolfenden E, Ebinger C, Yirgu G, Renne PR, Kelley SP (2005) Evolution of a volcanic rifted margin: Southern Red Sea, Ethiopia. Geol Soc Am Bull 117(7-8):846-864

Wright R, Pilger E (2008) Satellite observations reveal little interannual variability in the radiant flux from the Mount Erebus lava lake. J Volcanol Geotherm Res 177(3):687-694

Wright TJ, Ebinger CJ, Biggs J, Ayele A, Yirgu G, Keir D, Stork A (2006) Magma maintained rift segmentation at continental rupture in the 2005 Afar dyking episode. Nature 442:291294

Yirgu G, Philpotts A (2005) 09/2005 (BGVN 30:09) Bulletin of the Global Volcanism Network. Smithsonian Institute, Global Volcanism Program. www.si.edu. Accessed January 2011 